\title{
Global Rates and Prevalence of Urogenital Mycoplasmosis: Assembly of a Dataset from Peer-Reviewed Literature*
}

\author{
Jennifer A. Jones", Nufar Chaban", Meghan May ${ }^{\dagger}$ \\ Department of Biological Sciences, Fisher College of Science and Mathematics, Towson University, Towson, USA \\ Email: jjones39@students.towson.edu,nchaba1@students.towson.edu, ${ }^{\dagger}$ mmay@towson.edu
}

Received February 3, 2013; revised March 4, 2013; accepted March 11, 2013

Copyright (C) 2013 Jennifer A. Jones et al. This is an open access article distributed under the Creative Commons Attribution License, which permits unrestricted use, distribution, and reproduction in any medium, provided the original work is properly cited.

\begin{abstract}
Rates of urogenital mycoplasmosis associated with Mycoplasma genitalium, Mycoplasma hominis, Ureaplasma urealyticum, and Ureaplasma parvum have been reported numerous times, and frequently show a wide range of findings. Differing diagnostic techniques, population targeting, temporal and spatial data collection, and coincident infections make the conclusions from these analyses difficult to compare. We generated a single data set including the infection rate, geographic location, year, study population, diagnostic method, and clinical signs for these organisms by performing literature searches with the species names and compiling the findings. Studies focusing on basic research or reporting clinical surveys where these criteria were not reported were excluded. A statistical analysis of the dataset parameters found that: diagnostic method does not significantly correlate with positive specimen rate but does correlate with the year of publication, and the number of publications correlated significantly with year, indicating that this topic is of growing interest. Further analysis indicated that Ureaplasma species infection rate is significantly higher in pregnant women across all studies. Associations with distinct clinical presentation could not be made on datasets assembled across studies due to the number of confounding variables presented in each. The generated data set represents a large amount of temporal, geographic, and clinical data that can be utilized in future communications.
\end{abstract}

Keywords: Mycoplasma genitalium; Mycoplasma hominis; Ureaplasma; Urogenital Mycoplasma

\section{Introduction}

Members of the genera Mycoplasma and Ureaplasma are small, wall-less bacteria that parasitize vertebrate hosts in an obligate manner. Infections with these species exhibit a spectrum of clinical manifestations ranging from asymptomatic states to the classical manifestation of a chronic inflammatory illness that is not typically fatal. The primary sites of mycoplasmal infections are mucosal surfaces, and in humans infection is typically seen in the respiratory or urogenital tract. Urogenital mycoplasmosis of humans is typically associated with Mycoplasma genitalium (MG), Mycoplasma hominis (MH), Ureaplasma urealyticum (UU), Ureaplasma parvum (UP), or a complex infection of more than one of these species. Mycoplasma penetrans and Mycoplasma pirum are not commonly associated with clinical signs [1]. All of these species can be detected in clinically normal patients, but

\footnotetext{
*This work was supported by funds from the Robert M. Fisher Memorial Foundation (MM).

"These authors contributed equally to this work.

${ }^{\dagger}$ Corresponding author.
}

their association with urogenital disease has been the subject of extensive exploration.

Numerous studies have reported rates of patient infections in the context of their urogenital health with ambiguous results. The clinical states associated with Ureaplasma species (Usp) and $\mathrm{MH}$ appear to be strain- or patient-specific, and reportedly include nongonococcal urethritis (NGU) (Usp), bacterial vaginosis (MH), spontaneous abortion, or preterm labor (MH, Usp) [2]. In contrast, the causal role of MG in NGU, pelvic inflammatory disease, spontaneous abortion, and infertility is generally accepted, and as such it is now considered an emerging urogenital pathogen [3]. Infection of pregnant women with Usp has been associated with preterm labor and premature rupture of membranes, and the perinatal infants can develop Usp infections of the respiratory tract or central nervous system [4-6].

Diagnosis of urogenital mycoplasmosis was originally based on direct culture of MH or Usp from the urogenital tract, urine, semen, or cervical mucus, and often requires the services of a specialized laboratory [1]. Recovery of 
MG from affected tissues has historically been, and remains, particularly challenging. Due to the difficulties associated with culture, several other diagnostic methods have been developed and employed in recent years including polymerase chain reaction (PCR)-based nucleic acid detection strategies, serological diagnosis, and commercial assays based on detection of ammonia following the hydrolysis of urea (Usp) or catabolism of arginine (MH). Between the increased sensitivity of PCR and the technical limitations of culturing the organism, nucleic acid detection is used almost exclusively to diagnose $\mathrm{MG}$ infection.

Because the volume of clinical surveys investigating urogenital mycoplasmosis is large and the geographic location, study populations, clinical features, compounding factors, diagnostic methods, and clinical correlation with $\mathrm{MG}, \mathrm{MH}$, and Usp infection are disparate, we sought to compile a single data set describing the currently published clinical data on this topic and identify statistical trends across studies.

\section{Materials and Methods}

\subsection{Literature Analysis}

An analysis of primary literature was performed using the National Center for Biotechnology Information and the National Library of Medicine database PubMed. The search terms utilized were Mycoplasma genitalium, Mycoplasma hominis, and Ureaplasma. Studies describing basic research on the biology and/or pathogenicity of the bacteria were immediately excluded. The remaining medically-oriented studies were excluded if minimal clinical information was described, rates of infection were not provided, or differentiation between $\mathrm{MG}, \mathrm{MH}$, or Usp was not performed. The distinction was not drawn for $U$. urealyticum and $U$. parvum because many studies predate the description of the two distinct species. Studies were included if: 1) rates of definitive positive diagnosis of urogenital mycoplasmosis were reported, and 2) descriptions of associated clinical signs, the geographic origin of the samples, the diagnostic method, and the study population were reported. The dataset reflect studies published up to and including May 2011. Numbers of patients were sorted by clinical presentations and detected species. Asymptomatic control patients from each study were included in the dataset.

\subsection{Statistical Analysis}

Pearson correlation analysis between year and citations was performed. Spearman rank correlations between incidence in clinically affected individuals for each species and year, and incidence and diagnostic method were performed. Individual types of the categorical variable "diagnostic method" were assigned numeric values based on the sensitivity of the method (nucleic acid detection $=1$; commercial diagnostic kits $=2$, non-commercial ELISA $=3$, laboratory culture $=4$ ). The significance of incidence in pregnant vs. nonpregnant women was determined by $\chi^{2}$ analysis. All statistical procedures were performed using Origin 8.6 (OriginLab Corporation, Northampton, MA), and a $P$ value of less than 0.05 was considered significant.

\section{Results}

\subsection{Description of Dataset}

A total 172 studies including data from 53 countries (in addition to Scotland and Palestine) on all populated continents were examined (Table S1). The studies were published between 1975 and 2011 in 85 different journals (Table 1). A total of 96,361 patients (27,952 for MG, 23,928 for MH, and 44,481 for Usp) were tested by one of four diagnostic methods. Different prevalence rates for each species were observed overall and for each clinical presentation (Table 2). Patient totals from individual studies are presented in Tables S2-S4 for MG, MH, and Usp, respectively. Rates of infection in patients with urethritis, adverse pregnancy outcomes, infertility, and inflammatory conditions of the genital tract are presented in Tables S5-S8, respectively.

\subsection{Statistical Analysis}

Significant correlations were found between the diagnostic method utilized and the year of publication (inverse, $P$ $<0.0001$ ), and the number of citations and year (direct, $P$ $<0.001$ ). The correlation between diagnostic method ranked by sensitivity and positive percent of the population tested was not significant (Table 3). Pregnant women were significantly $(P<0.005)$ more likely to be infected with Usp than nonpregnant women regardless of the presence or absence of symptoms. Pregnant women were significantly $(P<0.05)$ less likely to be infected with MG. Infection with MH had no significant association with pregnancy.

\section{Discussion}

An analysis of primary literature was performed, and a single dataset describing rates of urogenital mycoplasmosis was described. Significant correlations were found between the diagnostic method utilized and the year of publication (inverse, $P<0.0001$ ), and the number of citations and year (direct, $P<0.001$ ), indicating that increasing numbers of studies reporting incidence of urogenital mycoplasmosis as determined by more sensitive methods such as nucleic acid detection and commercial detection kits are being published. The country with the greatest number of distinct populations studied in publi- 
Table 1. Parameter totals of included studies.

\begin{tabular}{ccccc}
\hline Studies & Countries & Years & Journals & Diagnostic methods \\
\hline 172 & $53^{*}$ & $1975-2011$ & 85 & 4 \\
\hline
\end{tabular}

*Includes the territories of Scotland and Palestine.

Table 2. Patient totals ${ }^{\mathrm{a}}$.

\begin{tabular}{ccccccccccc}
\hline Species & Total & CA & UR & PTL & INF & INFL & PC & LBW/CLD & ASM & ND \\
\hline \multirow{2}{*}{ MG } & 1954 & 1023 & 795 & 13 & 45 & 157 & & & 681 & 250 \\
& 27952 & 15838 & 12264 & 650 & 303 & 2450 & - & - & 8304 & 3810 \\
\multirow{3}{*}{ MH } & 4104 & 1021 & 317 & 28 & 111 & 475 & 90 & & 621 & 2492 \\
& 23928 & 8229 & 4680 & 127 & 1130 & 1911 & 372 & - & 5632 & 10198 \\
& 14975 & 5749 & 2811 & 558 & 1300 & 508 & & 100 & 4353 & 4640 \\
Usp & 44481 & 17498 & 9792 & 1064 & 4053 & 1627 & & 284 & 13720 & 12828 \\
\hline
\end{tabular}

${ }^{a}$ Cells reflect the combined number of positives (top subcell) and number of patients tested across studies (bottom subcell). Abbreviations used: CA: clinically affected; UR: urethritis; PTL: preterm labor; INF: infertility; INFL: inflammatory conditions (i.e., bacterial vaginosis, cervicitis, pelvic inflammatory disease); PC: prostate cancer; LBW/CLD: low birth weight and/or chronic lung disease of infants; ASM: asymptomatic; ND: no description of specific clinical signs while being distinguished from asymptomatic patients.

Table 3. Study parameters.

\begin{tabular}{cccc}
\hline Statistical parameter & ${\text { Diagnostic method and \% } \text { infected }^{\mathbf{a}}}$ & Diagnostic method and year & Number of citations and year $^{\text {N/A }}$ \\
\hline Pearson coefficient & 0.127 & N/A & 0.455 \\
Spearman's rho & 0.085 & -0.738 & 0.477 \\
$P$ value & No & 0 & $0.008,0.009$ \\
Significant? & Yes, $P<0.0001$ & Yes, $P<0.01$ \\
\hline
\end{tabular}

${ }^{\mathrm{a}}$ Values from both all organisms and both symptomatic and asymptomatic patients included.

cations meeting our criteria was the United States (41), followed by Japan (26) and China (18). All populated continents were represented in our analysis.

Usp have consistently been reported at higher rates in pregnant women as compared to nonpregnant women, but associations with clinical signs have been inconsistent. The generation of pathologic lesions during mycoplasmosis can be both strain variable and dependent on host factors; however, the presence or absence of $\mathrm{MG}$, $\mathrm{MH}$, or Usp during pregnancy as an unambiguous condition allows for concrete analysis. Across studies, we found that Usp were detected in pregnant women significantly more often than nonpregnant women. The association of Usp with low birth weight and chronic lung disease in preterm infants has been established by multiple studies [4,5], illustrating the clinical importance of this association. We also found that pregnant women were significantly less likely to be infected with $\mathrm{MG}$; however, this likely represents an anomaly stemming from published study designs investigating $\mathrm{MG}$ and infertility. Women of infertile couples are often, but not always, significantly more likely to have MG infection than controls. The focus on infertility indicates the ideal asymptomatic control patients for such studies are pregnant women. It is far more probable that $\mathrm{MG}$ infection leads to infertility than pregnancy as a condition is somehow protective against MG infection.

The association of $\mathrm{MG}, \mathrm{MH}$ and Usp with specific urogential health concerns remains somewhat difficult to define because of the equivocal findings of a large number of clinical studies. Confounding factors such as coinfection with additional sexually transmitted pathogens, the narrow focus on nonrepresentative populations such as infertile couples or STI clinic patients, and the differing age of patients makes the combination of data for each pathogen across studies inadvisable. Previously described differences between strains of $\mathrm{MG}, \mathrm{MH}$, and Usp include antibiotic susceptibility patterns [7-11] and the expression or variation of certain virulence factors including adhesins [12,13], biofilm formation [14], and the multiple-banded antigen of Usp [15]. In addition, comparative analysis of the complete genomes of nineteen Ureaplasma strains (representing the fourteen serovars) revealed a greater predilection for UU to undergo horizontal gene transfer, making it more subject to genome plasticity than UP [16]. UU has been associated with more severe clinical presentations than UP [16], which is potentially explained by the acquisition of novel genes. In addition, the failure to speciate between the apparently more pathogenic UU and the apparently less 
pathogenic UP may contribute to the ambiguity of Usp in association with clinical presentations. Heterogeneity of all three pathogens undoubtedly contributes to the spectrum of clinical presentations ranging from asymptomatic carriage to chronic inflammatory disease. Furthermore, the immune and nutritional status of the patient likely impacts the presentation of disease.

Infection with MG has been associated with increased shedding of human immunodeficiency virus (HIV) particles in two distinct studies, indicating that MG may facilitate HIV transmission [17]. Additionally, the presence of genital tract white blood cells due to urogenital inflammation regardless of cause is association with increased HIV shedding [18]. Because of the public health implications of increased HIV transmission, the prevalence of agents capable of causing urogenital inflammation should thus be monitored. Compiling the findings of studies describing rates of urogenital mycoplasmosis in clinically affected and asymptomatic patients represents a step toward illustrating the presence of these pro-inflammatory organisms.

\section{Conclusion}

The value of the compiled dataset is the illustration of the numbers of patients being evaluated for $\mathrm{MG}, \mathrm{MH}$, and Usp. The parameters of the dataset illustrate increasing clinical interest in the incidence of urogenital mycoplasmosis, and that increasingly molecular methods are being used to detect the organisms. Confounding variables make the analysis of infection rates across all clinically affected versus all asymptomatically infected patients inadvisable; however, the generated dataset represents a large amount of temporal, geographic, and clinical data that can be utilized in future exchanges.

\section{REFERENCES}

[1] D. R. Brown, M. May, J. M. Bradbury, M. F. Balish, M. J. Calcutt, J. I. Glass, S. Tasker, J. B. Messick, K.-E. Johansson and H. Neimark, "Genus I. Mycoplasma.," In: N. R. Krieg, W. Ludwig, W. B. Whitman, B. P. Hedlund, B. J. Paster, J. T. Staley, N. Ward, D. R. Brown and A. Parte, Eds., Bergey's Manual of Systematic Bacteriology, Springer, Inc., New York, 2010 pp. 575-644.

[2] K. B. Waites and D. Talkington, "New Developments in Human Disease Due to Mycoplasmas," In: A. Blanchard and G. F. Browning, Eds., Mycoplasmas: Molecular Biology, Pathogenicity, and Strategies for Control, Horizon Bioscience, Norfolk, 2005, pp. 289-354.

[3] C. L. McGowin and C. Anderson-Smits, "Mycoplasma genitalium: An Emerging Cause of Sexually Transmitted Disease in Women," PLoS Pathogens, Vol. 7, No. 5, 2011, Article ID: e1001324.

[4] B. Larsen and J. Hwang, "Mycoplasma, Ureaplasma, and Adverse Pregnancy Outcomes: A Fresh Look," Infectious
Diseases in Obstetrics and Gynecology, Vol. 2010, 2010, Article ID: 521921. doi:10.1155/2010/521921

[5] R. M. Viscardi, "Ureaplasma Species: Role in Diseases of Prematurity," Clinics in Perinatology, Vol. 37, No. 2, 2010, pp. 393-409. doi:10.1016/j.clp.2009.12.003

[6] R. M. Viscardi, W. M. Manimtim, C. C. Sun, L. Duffy and G. H. Cassell, "Lung Pathology in Premature Infants with Ureaplasma urealyticum Infection," Pediatric and Developmental Pathology Vol. 5, No. 2, 2002, pp. 141-150.

[7] M. A. De Francesco, S. Caracciolo, C. Bonfanti and N. Manca, "Incidence and Antibiotic Susceptibility of Mycoplasma hominis and Ureaplasma urealyticum Isolated in Brescia, Italy, over 7 Years," Journal of Infection and Chemotherapy, 2012.

[8] R. Krausse and S. Schubert, "In-Vitro Activities of Tetracyclines, Macrolides, Fluoroquinolones and Clindamycin against Mycoplasma hominis and Ureaplasma ssp. Isolated in Germany over 20 Years," Clinical Microbiology and Infection, Vol. 16, No. 11, 2010, pp. 1649-1655. doi:10.1111/j.1469-0691.2010.03155.x

[9] Y. Shimada, T. Deguchi, K. Nakane, T. Masue, M. Yasuda, S. Yokoi, S. Ito, M. Nakano and H. Ishiko, "Emergence of Clinical Strains of Mycoplasma genitalium Harbouring Alterations in ParC Associated with Fluoroquinolone Resistance," International Journal of Antimicrobial Agents, Vol. 36, No. 3, 2010, pp. 255-258. doi:10.1016/j.ijantimicag.2010.05.011

[10] Y. Shimada, T. Deguchi, K. Nakane, M. Yasuda, S. Yokoi, S. Ito, M. Nakano and H. Ishiko, "Macrolide Resistance-Associated 23S rRNA Mutation in Mycoplasma genitalium, Japan," Emerging Infectious Diseases, Vol. 17, No. 6, 2011, pp. 1148-1150. doi:10.3201/eid1706.101055

[11] Y. Shimada, T. Deguchi, Y. Yamaguchi, M. Yasuda, K. Nakane, S. Yokoi, S. Ito, M. Nakano and H. Ishiko, "gyrB and parE Mutations in Urinary Mycoplasma genitalium DNA from Men with Non-Gonococcal Urethritis," International Journal of Antimicrobial Agents, Vol. 36, No. 5, 2010, pp. 477-478. doi:10.1016/i.ijantimicag.2010.07.013

[12] S. L. Iverson-Cabral, S. G. Astete, C. R. Cohen and P. A. Totten, "mgpB and mgpC Sequence Diversity in Mycoplasma Genitalium Is Generated by Segmental Reciprocal Recombination with Repetitive Chromosomal Sequences," Molecular Microbiology, Vol. 66, No. 1, 2007, pp. 55-73. doi:10.1111/j.1365-2958.2007.05898.x

[13] S. L. Iverson-Cabral, S. G. Astete, C. R. Cohen, E. P. Rocha and P. A. Totten, "Intrastrain Heterogeneity of the mgpB Gene in Mycoplasma genitalium Is Extensive in Vitro and in Vivo and Suggests That Variation Is Generated via Recombination with Repetitive Chromosomal Sequences," Infection and Immunity, Vol. 74, No. 7, 2006, pp. 3715-3726. doi:10.1128/IAI.00239-06

[14] K. Pandelidis, K. A. McCarthy, K. L. Chesko and R. M. Viscardi, "Role of Biofilm Formation in Ureaplasma Antibiotic Susceptibility and Development of Bronchopulmonary Dysplasia in Preterm Neonates," Pediatric Infectious Disease Journal, Vol. 32, No. 4, 2013, pp. 394-398.

[15] L. J. Teng, X. Zheng, J. I. Glass, H. L. Watson, J. Tsai and G. H. Cassell, "Ureaplasma urealyticum Biovar Spe- 
cificity and Diversity Are Encoded in Multiple-Banded Antigen Gene," Journal of Clinical Microbiology, Vol. 32, No. 6, 1994, pp. 1464-1469.

[16] V. Paralanov, J. Lu, L. B. Duffy, D. M. Crabb, S. Shrivastava, B. A. Methé, J. Inman, S. Yooseph, L. Xiao, G. H. Cassell, K. B. Waites and J. I. Glass, "Comparative Genome Analysis of 19 Ureaplasma urealyticum and Ureaplasma parvum Strains," BMC Microbiology, Vol. 12, 2012, p. 88.

[17] L. E. Manhart, S. B. Mostad, J. M. Baeten, S. G. Astete, K. Mandaliya and P. A. Totten, "High Mycoplasma Geni- talium Organism Burden Is Associated with Shedding of HIV-1 DNA from the Cervix," Journal of Infectious Diseases, Vol. 197, No. 5, 2008, pp. 733-736. doi:10.1086/526501

[18] C. L. McGowin, R. S. Annan, A. J. Quayle, S. J. Greene, L. Ma, M. M. Mancuso, D. Adegboye and D. H. Martin, "Persistent Mycoplasma genitalium Infection of Human Endocervical Epithelial Cells Elicits Chronic Inflammatory Cytokine Secretion," Infection and Immunity, Vol. 80, No. 11, 2012, pp. 3842-3849. doi:10.1128/IAI.00819-12 


\section{Supplement}

Table S1. Peer-reviewed studies represented in this dataset.

\begin{tabular}{|c|c|c|c|c|}
\hline $\begin{array}{l}\text { Study } \\
\text { number }\end{array}$ & First author & Title & Journal & Year \\
\hline 1 & Wetmore C.M. & \multicolumn{2}{|c|}{$\begin{array}{l}\text { Demographic, behavioral, and clinical characteristics of } \\
\text { men with non-gonococcal urethritis differ by etiology: A Journal of Infection and Chemotherapy } \\
\text { case-comparison study }\end{array}$} & 2011 \\
\hline 2 & Shigehara K. & $\begin{array}{l}\text { Prevalence of genital Mycoplasma, Ureaplasma, } \\
\text { Gardnerella, and human papillomavirus in Japanese men } \\
\text { with Urethritis, and risk factors for detection of urethral } \\
\text { human papillomavirus infection }\end{array}$ & Sexually Transmitted Diseases & 2011 \\
\hline 3 & Aydin Y. & $\begin{array}{l}\text { Association of cervical infection of Chlamydia } \\
\text { trachomatis, Ureaplasma urealyticum and Mycoplasma } \\
\text { hominis with peritoneum colonization in pregnancy }\end{array}$ & Journal of Obstetrics and Gyneacology & 2010 \\
\hline 4 & Vesic S. & $\begin{array}{l}\text { Chlamydia trachomatis and urogenital mycoplasmas in } \\
\text { nonconococcal in men }\end{array}$ & Medicinski Pregled & 2010 \\
\hline 5 & Govender S. & $\begin{array}{l}\text { Prevalence of genital mycoplasmas, ureaplasmas and } \\
\text { chlamydia in pregnancy }\end{array}$ & Journal of Obstetrics and Gynaecology & 2009 \\
\hline 6 & Mares M. & $\begin{array}{l}\text { The prevalence of some bacterial markers in female } \\
\text { patients undergoing an initial infertility evaluation in } \\
\text { north-east Romania }\end{array}$ & $\begin{array}{l}\text { Roumanian Archives of Microbiology and } \\
\text { Immunology }\end{array}$ & 2009 \\
\hline 7 & Barykova Iua. & $\begin{array}{l}\text { Identification of Mycoplasma in patients with suspected } \\
\text { prostate cancer }\end{array}$ & Oncotarget & 2010 \\
\hline 8 & Zeighami H. & $\begin{array}{l}\text { Detection of Ureaplasma urealyticum in semen of } \\
\text { infertile men by PCR }\end{array}$ & Pakistan Journal of Biological Sciences & 2007 \\
\hline 9 & Bujoid E. & $\begin{array}{l}\text { Bacteriology of Amniotic fluid in women with } \\
\text { suspected cervical insufficiency }\end{array}$ & $\begin{array}{l}\text { Journal of Obstetrics and Gynaecology } \\
\text { Canada }\end{array}$ & 2008 \\
\hline 10 & Hagerty C.L. & $\begin{array}{l}\text { Clinical characteristics of bacterial vaginosis among } \\
\text { women testing positive for fastidious bacteria }\end{array}$ & Sexually Transmitted Infections & 2009 \\
\hline 11 & Agbakoba N.R. & $\begin{array}{l}\text { PCR reaction assay of Ureaplasma strains isolated from } \\
\text { high vaginal swabs of wmen in Ibadan, Nigeria }\end{array}$ & $\begin{array}{l}\text { African Journal of Medicine and Medical } \\
\text { Sciences }\end{array}$ & 2008 \\
\hline 12 & Latthe P.M. & $\begin{array}{l}\text { Mycoplasma and Ureaplasma Colonization in women } \\
\text { with lower urinary tract symptoms }\end{array}$ & Journal of Obstetrics and Gynaecology & 2008 \\
\hline 13 & Gdoura R. & $\begin{array}{l}\text { Acreening for Bacterial Pathogens in Semen samples } \\
\text { from Infertile men with and without Leukocytospermia }\end{array}$ & Andrologia & 2008 \\
\hline 14 & Zheng J. & $\begin{array}{l}\text { [Ureaplasma urealyticum infection in the genital tract } \\
\text { reduces seminal quality in infertile men] }\end{array}$ & Zhonghua Nan Ke Xue & 2008 \\
\hline 15 & Kacerovský M. & $\begin{array}{l}\text { [Preterm premature rupture of membranes and } \\
\text { Ureaplasma urealyticum] }\end{array}$ & $\begin{array}{l}\text { Ceska gynekologie / Ceska lekarska } \\
\text { spolecnost J. Ev. Purkyne }\end{array}$ & 2008 \\
\hline 16 & Nassar F.A. & $\begin{array}{l}\text { Detection of Chlamydia trachomatis and Mycoplasma } \\
\text { hominis Genitalium and Ureaplasma urealyticum by } \\
\text { PCR in patients with sterile pyuria }\end{array}$ & Advances in Medical Sciences & 2008 \\
\hline 17 & Yu J.T. & $\begin{array}{l}\text { Asymptomatic urethral infection in male sexually } \\
\text { transmitted disease clinic attendees }\end{array}$ & International Journal of STD and AIDS & 2008 \\
\hline 18 & Zhang X. & $\begin{array}{l}\text { Risk factors of HIV infection and prevalence of } \\
\text { co-infections among men who have sex with men in } \\
\text { Beijing, China }\end{array}$ & $A I D S$ & 2007 \\
\hline 19 & Wenmen W.M. & $\begin{array}{l}\text { Demographic, clinical and microbiological } \\
\text { characteristics of maternity patients: A Canadian clinical } \\
\text { cohort study }\end{array}$ & $\begin{array}{l}\text { The Canadian Journal of Infectious } \\
\text { Diseases }\end{array}$ & 2002 \\
\hline 20 & Gdoura R. & $\begin{array}{l}\text { Ureaplasma urealyticum, Ureaplasma parvum, } \\
\text { Mycoplasma hominis and Mycoplasma Genitalium } \\
\text { infections and semen quality of infertile men }\end{array}$ & BMC Infectious Diseases & 2007 \\
\hline 21 & Di Bartolomeo S. & $\begin{array}{l}\text { [Prevalence for associated microorganisms in genital } \\
\text { discharge, Argentina] }\end{array}$ & Revista De Saude Publica & 2002 \\
\hline 22 & Castro-Alcaraz S. & $\begin{array}{l}\text { Patterns of Colonization with Ureaplasma urealyticum } \\
\text { during neonatal intensive care unit hospitalizations of } \\
\text { very low birth weight infants and the development of } \\
\text { chronic lung disease }\end{array}$ & Pediatrics & 2002 \\
\hline 23 & Odendaal H.J. & Preterm labor-Is Mycoplasma Hominis involved? & South African Medical Journal & 2002 \\
\hline
\end{tabular}




\section{Continued}

\begin{tabular}{|c|c|c|}
\hline 24 & Yu P. & $\begin{array}{l}\text { [Research in the relationship between Chlamydia and } \\
\text { Ureaplasma and infertility] }\end{array}$ \\
\hline 25 & Wang N. & $\begin{array}{l}\text { [Epidemiological study on mycoplasmas colonization } \\
\text { and infection in the female genital tract] }\end{array}$ \\
\hline 26 & Martens G. & $\begin{array}{l}\text { Presence of Chlamydia, Mycoplasma, Ureaplasma, and } \\
\text { other bacteria in the upper and lower genital tracts of } \\
\text { fertile and infertile populations }\end{array}$ \\
\hline 27 & Samra Z. & $\begin{array}{l}\text { Prevalence of sexually transmitted pathogens among } \\
\text { women attending a methadone clinic in Israel }\end{array}$ \\
\hline 28 & Gogate A. & $\begin{array}{l}\text { Mycoplasma hominis infections in female genital tract \& } \\
\text { use of immunofluoscence for antibody detection }\end{array}$ \\
\hline 29 & Yu P. & $\begin{array}{l}\text { [Research in the relationship between Chlamydia and } \\
\text { Ureaplasma and infertility] }\end{array}$ \\
\hline
\end{tabular}

$30 \quad$ Fenkci V

31 Domingues D.

32 Srugo

Rodriguez R.

Dyke M.P.

Romero R.

Valencia G.B.

Hillier S.L.

Martens M.G.

Szostek S.

Reid I.

Zhao J.

De Nader O.M.
Gonzalez-Pedraza A.
Have Ureaplasma urealyticum and Mycoplasma hominis infections any significant effect on women fertility?

Genital mycoplasmas in women attending a family planning clinic in Guine-Bissau and their susceptibility to antimicrobial agents

Agents of non-gonococcal urethritis in males attending an Israeli clinic for sexually transmitted diseases

[Role of bacteria associated with sexually transmitted infections in the etiology of lower urinary tract infection in primary care]

[Prevalence of associated microorganisms in genital discharge, Argentina]

Ureaplasma urealyticum biovar determintion in women attending a family planning clinic in Guine-Bissau, using polymerase chain reaction of the multiple-banded antigen gene

Di Bartolomeo S

[Genital infection and infertility]

[Microbiologic profile in symptomatic pregnant

women's genital secretions in Gran Buenos Aires, Argentina]

De Moreno N.O. [The presence of genital mycoplasmas in women of reproductive age]

Ureaplasma urealyticum in a neonatal intensive care population

Petitjean J.
Microbial invasion of the amniotic cavity during term labor. Prevalence and clinical significance

Mycoplasma hominis and Ureaplasma urealyticum in neonates with suspected infection

The normal vaginal flora, $\mathrm{H} 2 \mathrm{O} 2$-producing lactobacilli, and bacterial vaginosis in pregnant women

Presence of Chlamydia, Mycoplasma, Ureaplasma, and other bacteria in the upper and lower genital tracts of fertile and infertile populations

[Papilloma virus infections in women with cervical pathology]

[Mycoplasma hominis and Ureaplasma urealyticum in pregnant and infertile women. Differences in tubal pathology]

[A prospective study of mycoplasma infection in a neonatal unit]

[Study on the infections of U. urealyticum, M. Hominis, and C. trachomatis in patients with venereal diseases and Zhonghua Liu Xing Bing Xue Za Zhi healthy controls in three areas of China]

[Prevalence in Tucuman of Chlamydia trachomatis and Ureaplasma urealyticum in sexually active women] Society of America

Infectious Diseases in Obstetrics and Gynecology

Revista Chilena de Obstetricia y Ginecologia

Annales de Pediatrie
Bulletin of Hunan Medical University

Zhonghua Liu Xing Bing Xue Za Zhi

Infectious Diseases in Obstetrics and Gynecology

Genitourinary Medicine

The Indian Journal of Medical Research

Bulletin of Hunan Medical University

Le Infezioni in Medicina: Revista Periodica

di Eziological, Epidemiologica,

Diaonostica, Clinica Terapia delle

Patologie Infettive

Acta Tropica

The Israel Medical Association Journal

Enfermedades Infecciosas y Microbiologia Clinica

Revista de Saude Publica

Journal of Clinical Laboratory Analysis

Enfermedades Infecciosas y Microbiologia Clinica

Revista Medica de Panama

Journal of Paediatrcs and Child Health

The Journal of Reproductive Medicine

The Pediatric Infectious Disease Journal

Clinical Infectious Diseases: An official Publication of the Infectious Diseases

Medycyna Doswiadczalna I Mikrobiologia 


\section{Continued}

\begin{tabular}{|c|c|c|c|c|}
\hline 49 & Van Rensburg H.J. & $\begin{array}{l}\text { The prevalence of potential pathogenic micro-organisms } \\
\text { in the endocervix of pregnant women at Tygerberg } \\
\text { hospital }\end{array}$ & South African Medical Journal & 1992 \\
\hline 50 & Segonds C. & [Mycoplasmas and pregnancy. Preliminary study] & $\begin{array}{l}\text { Journal de Gynecologie, Obstetrique et } \\
\text { biologie de la Reproduction }\end{array}$ & 1992 \\
\hline 51 & Stefanik M. & Microbial causative agents of male urethritis & $\begin{array}{l}\text { Journal of Hygiene, Epidemiology, } \\
\text { Microbiology and Immunology }\end{array}$ & 1992 \\
\hline 52 & Wang N. & $\begin{array}{l}\text { [Genital mycoplasma colonization in the female genital } \\
\text { tract] }\end{array}$ & Zhonghua Fu Chan Ke Za Zhi & 1991 \\
\hline 53 & Takamizawa S. & $\begin{array}{l}\text { [A study of Ureaplasma urealyticum pathogenicity in } \\
\text { human genitourinary tract] }\end{array}$ & $\begin{array}{l}\text { The Journal of the Japanese Association } \\
\text { for Infectious Diseases }\end{array}$ & 1991 \\
\hline 54 & Matsudu T. & $\begin{array}{l}\text { [Ureaplasma urealyticum and Mycoplasma hominis in } \\
\text { male urethritis] }\end{array}$ & Hinyokika Kiyo. Acta Urologica Japonica & 1991 \\
\hline 55 & $\begin{array}{l}\text { Rodriguez-Pichardo } \\
\text { A. }\end{array}$ & $\begin{array}{l}\text { Sexually transmitted diseases in homosexual males in } \\
\text { Seville, Spain }\end{array}$ & Genitourinary Medicine & 1991 \\
\hline 56 & Montagut J.M. & Ureaplasma in semen and IVF & Human Reproduction & 1991 \\
\hline 57 & Orduna Domingo A. & $\begin{array}{l}\text { [Age and sex distribution of sexually transmitted disease } \\
\text { in Valladolid, A study of } 5076 \text { cases] }\end{array}$ & Revista de Sanidad e Higiene Publica & 1991 \\
\hline 58 & Lefevre J.C. & $\begin{array}{l}\text { Clinical and microbiologic features of urethritis in men } \\
\text { in Toulouse, France }\end{array}$ & Sexually Transmitted Diseases & 1991 \\
\hline 59 & Bucek R. & [Isolation of mycoplasmas from female genitalia] & $\begin{array}{l}\text { Ceskoslovenska Epidemiologie, } \\
\text { Mikrobiologie, Imunologie }\end{array}$ & 1989 \\
\hline 60 & Vonsee H.J. & $\begin{array}{l}\text { Detection of Chlamydia trachomatis, Mycoplasma } \\
\text { hominis and Ureaplasma urealyticum in pregnant Dutch } \\
\text { women }\end{array}$ & $\begin{array}{l}\text { European Journal of Obstetrics, } \\
\text { Gynecology, and Reproductive Biology }\end{array}$ & 1989 \\
\hline 61 & Deodhar L. & $\begin{array}{l}\text { Co-existence of } \mathrm{N} \text {. gonorrhoeae and } \mathrm{U} \text {. urealyticum in } \\
\text { male urethra }\end{array}$ & Journal of Postgraduate Medicine & 1989 \\
\hline 62 & Romero R. & $\begin{array}{l}\text { Is genital colonization with mycoplasma hominis or } \\
\text { ureaplasma urealyticum associated with prematurity/low } \\
\text { birth weight? }\end{array}$ & Obstetrics and Gynecology & 1989 \\
\hline 63 & Horvath B. & $\begin{array}{l}\text { Incidence of Mycoplasma hominis and Ureaplasma } \\
\text { urealyticum infection in pregnant women and } \\
\text { gynaecological patients; the effectivity of doxycycline } \\
\text { therapy }\end{array}$ & Therapia Hungarica & 1989 \\
\hline 64 & Vignjevic D. & [Genital infections in adolescence] & $\begin{array}{l}\text { Jugoslavenska Ginekologija I } \\
\text { Perinatologija }\end{array}$ & 1989 \\
\hline 65 & $\begin{array}{l}\text { Zurovac-Jovanovic } \\
\text { G. }\end{array}$ & $\begin{array}{l}\text { [The significance of Ureaplasma urealyticum and } \\
\text { Mycoplasma hominis in non-specific urethritis] }\end{array}$ & Medicinski Arhiv & 1989 \\
\hline 66 & Hackel H. & $\begin{array}{l}\text { Prevalence of Ureaplasma urealyticum in the urethra of } \\
\text { men without urethritis in relation to clinical diagnosis }\end{array}$ & Dermotologica & 1990 \\
\hline 67 & Narcio Reyes M.L. & $\begin{array}{l}\text { [Etiology of cervicovaginal infection in pregnant and } \\
\text { non-pregnant patients] }\end{array}$ & Ginecologia y Obstetricia de Mexico & 1989 \\
\hline 68 & Jacob-Cormier B. & [Ureaplasma urealyticum and chorioamnionitis] & $\begin{array}{l}\text { Revue Francaise de Gynecologie et } \\
\text { D'Obstetrique }\end{array}$ & 1989 \\
\hline 69 & Bernal J.N. & $\begin{array}{l}\text { [Diagnosis of sexually transmitted diseases in Chilean } \\
\text { pregnant adolescents] }\end{array}$ & $\begin{array}{l}\text { Revista Chilena de Obstetricia y } \\
\text { Ginecologia }\end{array}$ & 1989 \\
\hline 70 & Kawamura N. & $\begin{array}{l}\text { Isolation of ureaplasma urealyticum from urological out } \\
\text { patients }\end{array}$ & Hinyokika Kiyo. Acta Urologica Japonica & 1988 \\
\hline 71 & Vitoratos N. & $\begin{array}{l}\text { Sexually transmitted diseases in women with urethral } \\
\text { syndrome }\end{array}$ & $\begin{array}{l}\text { International Journal of Gynecology and } \\
\text { Obstetrics }\end{array}$ & 1988 \\
\hline 72 & Sanchez P.J. & $\begin{array}{l}\text { Ureaplasma urealyticum colonization and chronic lung } \\
\text { disease in low birth weight infants }\end{array}$ & The Pediatric Infectious Disease Journal & 1988 \\
\hline 73 & Kovacs G.T. & $\begin{array}{l}\text { Microbiological profile of the cervix in } 1,000 \text { sexually } \\
\text { active women }\end{array}$ & $\begin{array}{l}\text { Australian and New Zealand Journal of } \\
\text { Obstetrics and Gynaecology }\end{array}$ & 1988 \\
\hline 74 & Smith P.B. & $\begin{array}{l}\text { Predominant sexually transmitted diseases among } \\
\text { different age and ethnic groups of indigent sexually } \\
\text { active adolescents attending a family planning clinic }\end{array}$ & $\begin{array}{l}\text { Journal of Adolescent Health Care: } \\
\text { Official publication of the Society for } \\
\text { Adolescent Medicine }\end{array}$ & 1988 \\
\hline
\end{tabular}




\section{Continued}

\begin{tabular}{|c|c|c|}
\hline 75 & Schmidt U. & [Pathogen spectrum of non-gonorrhea urethritis] \\
\hline 76 & Smith J.L. & $\begin{array}{l}\text { Prevalence of Chlamydia trachomatis and the genital } \\
\text { mycoplasmas in a nonmetropolitan population }\end{array}$ \\
\hline 77 & Kanamoto Y. & $\begin{array}{l}\text { Colonization with genital mycoplasmas in pregnant } \\
\text { women and their neonates and birth weight }\end{array}$ \\
\hline
\end{tabular}

Elsner P.
Russo J.F.

Krausse R.

Tjiam K.H.

Naessens A.

Robertson J.A.

Iwasaka T.

Amortegul A.J.

McCormack W.M.

Bump R.C.

Nayyar K.C.

Naessens A.

Iwasaka $\mathrm{T}$.

Moller B.R.

Hardy P.H.

Busolo F.

Harrison H.R.

Peeters M.F.

Jahn G.

Quinn P.A.

Munday P.E.
Sexually transmittable organisms in the urethra of males with and without urethritis

[Isolation of Mycoplasma and Chlamydia in patients with urogenital infections]

Sexually communicable micro-organisms in human semen samples to be used for artificial insemination by donor

Epidemiology and pathogenesis of Ureaplasma urealyticum in spontaneous abortion and early preterm labor

Serotypes of Ureaplasma Urealyticum in spontaneous abortion

Hormonal status and mycoplasma colonization in the female genital tract

Prevalence of Chlamydia trachomatis and other micro-organisms in women seeking abortions in Pittsburgh, Pennsylvania, United States of America

Vaginal colonization with mycoplasma hominis and Ureaplasma urealyticum

Sexually transmissible infectious agents in sexually active and virginal asymptomatic adolescent girls

Prevalence of genital pathogens among female prostitutes in New York City and in Rotterdam

Recovery of microorganisms in semen and relationship to semen evaluation

Genital mycoplasma colonization in neonatal girls

Chlamydia, mycoplasmas, ureaplasmas, and yeasts in lower genital tract of females. Comparison between a group attending a venereal disease clinic and a control group

Prevalence of six sexually transmitted disease agents among pregnant inner-city adolescents and pregnancy out come

Microbial Flora in semen of asymptomatic infertile men

The prevalence of genital chlamydia trachomatis and mycoplasmal infections during pregnancy in an American Indian population

Role of mycoplasmas in chronic prostatis

Gonorrheal urethritis - frequently a mixed chlamydia and Mycoplasma infection. Results in 143 male patients

Serologic evidence of Ureaplasma urealyticum infection in women with spontaneous pregnancy loss

Mycoplasma hominis, ureaplasma urealyticum, and corynebacterium Genitalium recovered from the lower genital tracts of adolescent women

Clinical and microbiological study of non-gonococcal urethritis with particular reference to non-chlamydial disease with acute gonorrhea
Zeitschrift fur Urologie und Nephrologie

International Journal of Fertility

Zentralblatt fur Bakteriologie,

Mikrobiologie, und Hygiene. Series A,

Medical Microbiology, Infectious Diseases,

Virology, Parasitology

Zentralblatt für Bakteriologie,

Mikrobiologie und Hygiene. Series A:

Medical Microbiology, Infectious Diseases, Virology, Parasitology

Immunitat und Infektion

Genitourinary Medicine

Acta Obstetricia et Gynecologia

Scandinavica

Pediatric Infectious Disease

Obstetrics and Gynecology

Genitourinary Medicine

Sexually Transmitted Diseases

Pediatrics

Sexually Transmitted Diseases

Fertility and Sterility

Acta Obstetricia et Gynecologia

Scandinavica

1986

Acta Obstetricia et Gynecologia

Scandinavica

Lancet

Andrologia

Sexually Transmitted Diseases

The Yale Journal of Biology and Medicine

Deutsche Medizinische Wochenschrift

American Journal of Obstetrics and Gynecology

International Journal of Gynaecology and Obstetrics: Official Organ of the International Federation of Gynaecology and Obstetrics

British Journal of Venereal Diseases 


\section{Continued}

\begin{tabular}{|c|c|c|c|c|}
\hline 99 & McDowall D.R. & $\begin{array}{l}\text { Anaerobic and other fastidious microorganisms in } \\
\text { asymptomatic bacteriuria in pregnant women }\end{array}$ & The Journal of Infectious Diseases & 1981 \\
\hline 100 & Hunter J.M. & $\begin{array}{l}\text { Chlamydia trachomatis and Ureaplasma urealyticum in } \\
\text { men attending a sexually transmitted disease clinic }\end{array}$ & British Journal of Venereal Diseases & 1981 \\
\hline 100 & Russo J.F. & $\begin{array}{l}\text { Preliminary study of the flora in the lower genital tracts } \\
\text { of sexually active adolescent females in relation to } \\
\text { symptoms and inflammatory response }\end{array}$ & $\begin{array}{l}\text { Journal of Adolescent Health Care: The } \\
\text { Official Publication of the Society for } \\
\text { Adolescent Medicine }\end{array}$ & 1981 \\
\hline 100 & McCormack W.M. & $\begin{array}{l}\text { Sexually transmitted conditions among women college } \\
\text { students }\end{array}$ & $\begin{array}{l}\text { American Journal of Obstetrics and } \\
\text { Gynecology }\end{array}$ & 1981 \\
\hline 101 & Weidner W. & $\begin{array}{l}\text { Quantitative culture of ureaplasma urealyticum in } \\
\text { patients with chronic prostatitis of prostatosis }\end{array}$ & The Journal of Urology & 1980 \\
\hline 102 & Giacomini $\mathrm{T}$. & $\begin{array}{l}\text { A systematic search for Ureaplasma urealyticum in } \\
\text { vaginal swabs. }\end{array}$ & $\begin{array}{l}\text { Journal de Gynecologie, Obstetrique, et } \\
\text { Biologie de la Reproduction }\end{array}$ & 1980 \\
\hline 103 & Nagata Y. & Mycoplasma infection and infertility & Fertility and Sterility & 1979 \\
\hline 104 & Hofmann N. & $\begin{array}{l}\text { Significance of Ureaplasma urealyticum in the sperm of } \\
\text { fertility patients }\end{array}$ & Zeitschrift fur Hautkrankheiten & 1979 \\
\hline 105 & Taylor-Robinson D. & $\begin{array}{l}\text { Ureaplasma urealyticum and Mycoplasma hominis in } \\
\text { chlamydial and non-chlamydial nongonococcal urethritis }\end{array}$ & British Journal of Venereal Diseases & 1979 \\
\hline 106 & Bowie W.R. & $\begin{array}{l}\text { Etiologies of postgonococcal urethritis in homosexual } \\
\text { and heterosexual men; roles of Chlamydia trachomatis } \\
\text { and Ureaplasma urealyticum }\end{array}$ & Sexually Transmitted Diseases & 1978 \\
\hline 107 & Wong J.L. & $\begin{array}{l}\text { The etiology of nongonococcal urethritis in men } \\
\text { attending a venereal disease clinic }\end{array}$ & Sexually Transmitted Diseases & 1977 \\
\hline 108 & Foy H. & $\begin{array}{l}\text { Prevalence of Mycoplasma hominis and Ureaplasma } \\
\text { urealyticum (T strains) in urine of adolescents }\end{array}$ & Journal of Clinical Microbiology & 1975 \\
\hline 109 & Gatski M. & $\begin{array}{l}\text { Mycoplasma genitalium infection among HIV-positive } \\
\text { women: Prevalence, risk factors and association with } \\
\text { vaginal shedding }\end{array}$ & International Journal of STDs \& AIDS & 2011 \\
\hline 110 & Mansson F. & $\begin{array}{l}\text { High prevalence of HIV-1, HIV-2 and other sexually } \\
\text { transmitted infections among women attending two } \\
\text { sexual health clinics in Bissau, Guinea-Bissau, West } \\
\text { Africa }\end{array}$ & International Journal of STDs \& AIDS & 2010 \\
\hline 111 & Thurman A.R. & $\begin{array}{l}\text { Mycoplasma genitalium symptoms, concordance and } \\
\text { treatment in high-risk sexual dyads }\end{array}$ & International Journal of STDs \& AIDS & 2010 \\
\hline 112 & Hitti J. & $\begin{array}{l}\text { Correlates of cervical Mycoplasma genitalium and risk } \\
\text { of preterm birth among Peruvian women }\end{array}$ & Sexually Transmitted Diseases & 2010 \\
\hline 113 & da Costa F.A. & $\begin{array}{l}\text { Prevalence of Mycoplasma genitalium among } \\
\text { HIV-infected men in São Paulo city detected by realtime } \\
\text { polymerase chain reaction }\end{array}$ & International Journal of STDs \& AIDS & 2010 \\
\hline 114 & Bjartling $\mathrm{C}$. & $\begin{array}{l}\text { The association between Mycoplasma genitalium and } \\
\text { pelvic inflammatory disease after termination of } \\
\text { pregnancy }\end{array}$ & $\begin{array}{l}\text { BJOG: An International Journal of } \\
\text { Obstetrics and Gynaecology }\end{array}$ & 2010 \\
\hline 115 & Gaydos C. & $\begin{array}{l}\text { Mycoplasma genitalium as a contributor to the multiple } \\
\text { etiologies of cervicitis in women attending sexually } \\
\text { transmitted disease clinics }\end{array}$ & Sexually Transmitted Diseases & 2009 \\
\hline 116 & Gaydos C. & $\begin{array}{l}\text { Mycoplasma genitalium compared to chlamydia, } \\
\text { gonorrhoea and trichomonas as an aetiological agent of } \\
\text { urethritis in men attending STD clinics }\end{array}$ & Sexually Transmitted Infections & 2009 \\
\hline 117 & Uno $\mathrm{M}$. & $\begin{array}{l}\text { Prevalence of Mycoplasma genitalium in men with } \\
\text { gonococcal urethritis }\end{array}$ & International Journal of STDs \& AIDS & 1996 \\
\hline 118 & Hussain A.I. & $\begin{array}{l}\text { Mycoplasma penetrans and other mycoplasmas in urine } \\
\text { of human immunodeficiency virus-positive children }\end{array}$ & Journal of Clinical Microbiology & 1999 \\
\hline 119 & Chandeyind V. & $\begin{array}{l}\text { The prevalence of urethral infections amongst } \\
\text { asymptomatic young men in Hat Yai, southern Thailand }\end{array}$ & International Journal of STDs \& AIDS & 2000 \\
\hline 120 & Cordova C.M. & $\begin{array}{l}\text { Higher prevalence of urogenital mycoplasmas in human } \\
\text { immunodeficiency virus-positive patients as compared } \\
\text { to patients with other sexually transmitted diseases }\end{array}$ & Journal of Clinical Laboratory Analysis & 2000 \\
\hline 121 & Sun R. & $\begin{array}{l}\text { Studies on the infection status of seven species } \\
\text { Mycoplasma, three species of Chlamydia, Neisseria } \\
\text { gonorrhoeae and Garderella vaginalis in } 76 \text { patients with } \\
\text { sexual transmitted diseases [translated from chinese] }\end{array}$ & Zhonghua Liu Xing Bing Xue Za Zhi & 2004 \\
\hline
\end{tabular}




\section{Continued}

\begin{tabular}{|c|c|c|c|c|}
\hline 122 & Anagrius $\mathrm{C}$. & $\begin{array}{l}\text { Mycoplasma genitalium: prevalence, clinical } \\
\text { significance, and transmission }\end{array}$ & Sexually Transmitted Infections & 2005 \\
\hline 123 & Cohen C.R. & $\begin{array}{l}\text { Mycoplasma genitalium infection and persistence in a } \\
\text { cohort of female sex workers in Nairobi, Kenya }\end{array}$ & Sexually Transmitted Diseases & 2007 \\
\hline 124 & Andersen B. & $\begin{array}{l}\text { Mycoplasma genitalium: prevalence and behavioural } \\
\text { risk factors in the general population }\end{array}$ & Sexually Transmitted Infections & 2007 \\
\hline 125 & Tosh A.K. & $\begin{array}{l}\text { Mycoplasma genitalium among adolescent women and } \\
\text { their partners }\end{array}$ & $\begin{array}{l}\text { Journal of Adolescent Health Care: The } \\
\text { Official Publication of the Society for } \\
\text { Adolescent Medicine }\end{array}$ & 2007 \\
\hline 126 & Manhart L.E. & $\begin{array}{l}\text { Mycoplasma genitalium among young adults in the } \\
\text { United States: An emerging sexually transmitted } \\
\text { infection }\end{array}$ & American Journal of Public Health & 2007 \\
\hline 127 & Hamasuna R. & $\begin{array}{l}\text { Prevalence of Mycoplasma genitalium among female } \\
\text { students in vocational schools in Japan }\end{array}$ & Sexually Transmitted Infections & 2008 \\
\hline 128 & Lawton B.A. & $\begin{array}{l}\text { High prevalence of Mycoplasma genitalium in women } \\
\text { presenting for termination of pregnancy }\end{array}$ & Contraception & 2008 \\
\hline 129 & Grzesko J. & $\begin{array}{l}\text { Occurrence of Mycoplasma genitalium in fertile and } \\
\text { infertile women. }\end{array}$ & Fertility and Sterility & 2009 \\
\hline 130 & Arraiz R.N. & $\begin{array}{l}\text { Mycoplasma genitalium detection and correlation with } \\
\text { clinical manifestations in population of the Zulia State, } \\
\text { Venezuela [article in Spanish] }\end{array}$ & $\begin{array}{l}\text { Revista Chilena de Infectologia: Organo } \\
\text { Oficial de la Sociedad Chilena de } \\
\text { Infectologia }\end{array}$ & 2008 \\
\hline 131 & $\begin{array}{l}\text { Moi, H. } \\
\text { Norway, Oslo }\end{array}$ & $\begin{array}{l}\text { Mycoplasma genitalium in women with lower genital } \\
\text { tract inflammation }\end{array}$ & Sexually Transmitted Infections & 2009 \\
\hline 132 & Moi H. & $\begin{array}{l}\text { Mycoplasma genitalium is associated with symptomatic } \\
\text { and asymptomatic non-gonococcal urethritis in men }\end{array}$ & Sexually Transmitted Infections & 2009 \\
\hline 133 & Simms I. & $\begin{array}{l}\text { Associations between Mycoplasma genitalium, } \\
\text { Chlamydia trachomatis, and pelvic inflammatory disease }\end{array}$ & Journal of Clinical Pathology & 2003 \\
\hline 134 & Luo D. & $\begin{array}{l}\text { Isolation and identification of Mycoplasma genitalium } \\
\text { from high risk populations of sexually transmitted } \\
\text { diseases in China }\end{array}$ & Chinese Medical Journal & 1999 \\
\hline 135 & Clausen H.F. & $\begin{array}{l}\text { Serological investigation of Mycoplasma genitalium in } \\
\text { infertile women }\end{array}$ & Human Reproduction & 2001 \\
\hline 136 & Pepin J. & $\begin{array}{l}\text { Etiology of urethral discharge in West Africa: the role of } \\
\text { Mycoplasma genitalium and Trichomonas vaginalis }\end{array}$ & Bulletin of the World Health Organization & 2001 \\
\hline 137 & Savio M.L. & $\begin{array}{l}\text { Detection of Mycoplasma genitalium from urethral } \\
\text { swabs of human immunodeficiency virus-infected } \\
\text { patients }\end{array}$ & The New Microbiologia & 1996 \\
\hline 138 & Uno $\mathrm{M}$. & $\begin{array}{l}\text { Prevalence of Mycoplasma genitalium in asymptomatic } \\
\text { men in Japan }\end{array}$ & International Journal of STDs \& AIDS & 1997 \\
\hline 139 & Uno $\mathrm{M}$. & $\begin{array}{l}\text { Mycoplasma genitalium in the cervices of Japanese } \\
\text { women }\end{array}$ & Sexually Transmitted Diseases & 1997 \\
\hline 140 & $\begin{array}{l}\text { Maeda S. } \\
\text { Japan }\end{array}$ & $\begin{array}{l}\text { Detection of Mycoplasma genitalium in patients with } \\
\text { urethritis (Men) }\end{array}$ & Journal of Urology & 1998 \\
\hline 141 & Bjornelius E. & $\begin{array}{l}\text { Mycoplasma genitalium in non-gonococcal urethritis- } \\
\text { a study in Swedish male STD patients }\end{array}$ & International Journal of STDs \& AIDS & 2000 \\
\hline 142 & Johannisson G. & $\begin{array}{l}\text { Occurrence and treatment of Mycoplasma genitalium in } \\
\text { patients visiting STD clinics in Sweden }\end{array}$ & International Journal of STDs \& AIDS & 2000 \\
\hline 143 & Faye-Kette H. & $\begin{array}{l}\text { Genital mycoplasmas among pregnant women in Cóte } \\
\text { d'Ivoire, West Africa: prevalence and risk factors }\end{array}$ & International Journal of STDs \& AIDS & 2000 \\
\hline 144 & Gangaram H.B. & $\begin{array}{l}\text { Urethritis in men at the Genito-Urinary Medicine Clinic } \\
\text { Kuala Lumpur Hospital }\end{array}$ & The Medical Journal of Malaysia & 2003 \\
\hline 145 & Rempel E.G. & $\begin{array}{l}\text { Comparison of various PCR methods for the detection of } \\
\text { Chlamydia trachomatis, Ureaplasma urealyticum, and } \\
\text { Mycoplasma hominis in women with impaired } \\
\text { reproductive function [article in Russian] }\end{array}$ & $\begin{array}{l}\text { Zhurnal Mikrobiologii, Epidemiologii, I } \\
\text { Immunobiologii }\end{array}$ & 2000 \\
\hline 146 & Kuvanont K. & Etiology of urethritis in Thai men & Sexually Transmitted Diseases & 1989 \\
\hline 147 & Tomioka E.S. & $\begin{array}{l}\text { Sexually transmitted agents in gynecology: Incidence } \\
\text { and importance [article in Portuguese] }\end{array}$ & Jornal Brasileiro de Ginecologia & 1987 \\
\hline
\end{tabular}




\section{Continued}

\begin{tabular}{|c|c|c|}
\hline 148 & Keane F.E. & $\begin{array}{l}\text { The association of Mycoplasma hominis, Ureaplasma } \\
\text { urealyticum and Mycoplasma genitalium with bacterial } \\
\text { vaginosis: observations on heterosexual women and their } \\
\text { male partners }\end{array}$ \\
\hline 149 & Morency P. & $\begin{array}{l}\text { Aetiology of urethral discharge in Bangui, Central } \\
\text { African Republic }\end{array}$ \\
\hline 150 & Temmerman M. & $\begin{array}{l}\text { Microbial aetiology and diagnostic criteria of postpartum } \\
\text { endometritis in Nairobi, Kenya }\end{array}$ \\
\hline 151 & Mobarak A. & $\begin{array}{l}\text { Ureaplasma urealyticum as a causative organism of } \\
\text { urinary tract infection stones }\end{array}$ \\
\hline 152 & Agbakoba N.R. & $\begin{array}{l}\text { Polymerase chain reaction assay of ureaplasma strains } \\
\text { isolated from high vaginal swabs of women in Ibadan, } \\
\text { Nigeria }\end{array}$ \\
\hline 153 & Gupta V. & $\begin{array}{l}\text { Detection and biovar discrimination of Ureaplasma } \\
\text { urealyticum in Indian patients with genital tract } \\
\text { infections }\end{array}$ \\
\hline 154 & Doh K. & $\begin{array}{l}\text { Differential vaginal expression of interleukin-1 system } \\
\text { cytokines in the presence of Mycoplasma hominis and } \\
\text { Ureaplasma urealyticum in pregnant women }\end{array}$ \\
\hline 155 & Ondondo R.O. & $\begin{array}{l}\text { Differential association of ureaplasma species with } \\
\text { non-gonococcal urethritis in heterosexual men }\end{array}$ \\
\hline
\end{tabular}

156 Totten P.A.

157 Mena L.

158 Arraiz R.N.

159 Yu J.T.

160

161 Hilton J.

162 Gambini D.

163

Sturm P.D.

164

Black V.

Association of Mycoplasma genitalium with nongonococcal urethritis in heterosexual men

Mycoplasma genitalium infections in asymptomatic men and men with urethritis attending a sexually transmitted diseases clinic in New Orleans

Mycoplasma genitalium detection and correlation with clinical manifestations in population of the Zulia State, Venezuela [article in Spanish]

Role of Mycoplasma genitalium and Ureaplasma urealyticum in non-gonococcal urethritis in Hong Kong

Observations on the microbiology of urethritis in black South African men

A case-control study of men with non-gonococcal urethritis at Auckland Sexual Health Service: rates of detection of Mycoplasma genitalium

Mycoplasma genitalium in males with nongonococcal urethritis: prevalence and clinical efficacy of eradication

Aetiology of male urethritis in patients recruited from a population with a high HIV prevalence

The detection of urethritis pathogens among patients with the male urethritis syndrome, genital ulcer syndrome and HIV voluntary counselling and testing

Taylor-Robinson D. clients: should South Africa's syndromic management approach be revised?

Association of Mycoplasma genitalium with acute

Manhart L.E.

Barykova Y.A.

McKechnie M.L. with gonococcal and chlamydial urethritis

High Mycoplasma genitalium organism burden is associated with shedding of HIV-1 DNA from the cervix

Association of Mycoplasma hominis infection with prostate cancer

The prevalence of urogenital micro-organisms detected by a multiplex PCR-reverse line blot assay in women attending three sexual health clinics in Sydney, Australia Microbial invasion and cytokine response in amniotic

169 Jacobsson B. fluid in a Swedish population of women with preterm prelabor rupture of membranes

170 Piot P. Isolation of Mycoplasma hominis from genital ulcerations of patients in Eastern and Southern Africa Chlamydia trachomatis, Mycoplasma genitalium and

171 Jensen A.J.

Ureaplasma urealyticum among students in northern Norway
International Journal of STDs \& AIDS

2000

Sexually Transmitted Infections

Genitourinary Medicine

Journal of the Egyptian Public Health Association

African Journal of Medicine and Medical Sciences

Diagnostic Microbiology and Infectious Disease

Infectious diseases in obstetrics and gynecology

Sexually Transmitted Infections

Journal Infectious Diseases

Clinical Infectious Diseases: An official publication of the Infectious Diseases Society of America

Revista Chilena de Infectologia: Organo Oficial de la Sociedad Chilena de Infectologia

Hong Kong Medical Journal

International Journal of STDs \& AIDS

Sexual Health

Sexually Transmitted Diseases

International Journal of Antimicrobial Agents

2004

Sexually Transmitted Infections

2008

Journal of Infectious Diseases

Oncotarget

Journal of Medical Microbiology

Acta Obstetricia et Gynecologia Scandinavica

Sexually Transmitted Diseases 
Table S2. Rates and clinical presentations of Mycoplasma genitalium.

\begin{tabular}{|c|c|c|c|c|c|c|c|c|c|}
\hline $\begin{array}{l}\text { Study } \\
\text { number }\end{array}$ & Location & Continent & Population & $\begin{array}{l}\text { Total } \\
\text { tested }\end{array}$ & \#Positive & MG \% & Presentation & Year & $\begin{array}{l}\text { Diagnostic } \\
\text { method }\end{array}$ \\
\hline 130 & Venezuela & South America & Gyn patients & 172 & 13 & 7.5 & "Symptomatic" & 2008 & PCR \\
\hline 148 & UK & Europe & Women w/o BV & 17 & 2 & 12 & BV & 2000 & PCR \\
\hline 115 & $\begin{array}{l}\text { USA } \\
\text { (Baltimore) }\end{array}$ & North America & Women at STI clinics & 324 & 93 & 28.6 & Cervicitis & 2009 & PCR \\
\hline 139 & Japan & Asia & $\begin{array}{l}\text { Women with } \\
\text { cervicitis/adnexitis }\end{array}$ & 103 & 7 & 6.8 & Cervicitis/adnex & 1997 & PCR \\
\hline 129 & Poland & Europe & Infertile women & 51 & 10 & 19.6 & Infertility & 2008 & PCR \\
\hline 135 & Denmark & Europe & Infertile women & 132 & 29 & 22 & Infertility & 2000 & serology \\
\hline 131 & Norway & Europe & Female STI clinic patients & 7646 & 344 & 4.5 & LGTI, urethritis & 2009 & PCR \\
\hline 1 & USA (Seattle) & North America & Men STI clinic & 370 & 46 & 12.5 & NGU & 2011 & PCR \\
\hline 17 & $\begin{array}{l}\text { China } \\
\text { (Hong Kong) }\end{array}$ & Asia & Male STI clinic patients & 36 & 5 & 13.9 & NGU & 2007 & PCR \\
\hline 120 & Brazil & South America & HIV men w/NGU & 110 & 10 & 9.1 & NGU & 2000 & $\begin{array}{l}\text { Culture- } \\
>\text { PCR/RFLP }\end{array}$ \\
\hline 149 & $\begin{array}{l}\text { Central African } \\
\text { Republic }\end{array}$ & Africa & Men STI clinic & 100 & 15 & 15 & NGU & 2001 & PCR \\
\hline 156 & USA & North America & Asympt controls & 125 & 5 & 4 & NGU & 2001 & PCR \\
\hline 157 & $\begin{array}{l}\text { USA (New } \\
\text { Orleans) }\end{array}$ & North America & Asympt controls & 184 & 13 & 7 & NGU & 2002 & PCR \\
\hline 158 & Venezuela & South America & Asympt controls & 172 & 7 & 4.1 & NGU & 2008 & PCR \\
\hline 133 & UK & Europe & PID patients & 46 & 6 & 13 & PID & 2003 & PCR \\
\hline 117 & Japan & Asia & $\begin{array}{l}\text { Men with gonococcal } \\
\text { urethritis }\end{array}$ & 45 & 2 & 4.4 & $\begin{array}{l}\text { Postgonococcal } \\
\text { urethritis }\end{array}$ & 1996 & PCR \\
\hline 114 & Sweden & Europe & $\begin{array}{l}\text { Pregnant women-induced } \\
\text { abortion }\end{array}$ & 1960 & 49 & 2.5 & Post term PID & 2007 & PCR \\
\hline 112 & Peru & South America & Pregnant women & 650 & 13 & 2 & Preterm labor & 2010 & PCR \\
\hline 16 & Palestine & Middle East & Sterile pyuria patients & 200 & 6 & 3 & Pyuria & 2008 & PCR \\
\hline 136 & $\begin{array}{l}\text { West Africa ( } 7 \\
\text { countries) }\end{array}$ & Africa & Male urethritis patients & 659 & 66 & 10 & Urethral discharge & 2001 & PCR \\
\hline 2 & Japan & Asia & Male urethritis patients & 178 & 32 & 18 & Urethritis & 2011 & PCR \\
\hline 116 & $\begin{array}{l}\text { USA } \\
\text { (Baltimore) }\end{array}$ & North America & Men at STI clinics & 153 & 34 & 22.2 & Urethritis & 2009 & PCR \\
\hline 122 & Sweden & Europe & Men at STI clinics & 451 & 27 & 6 & Urethritis & 2005 & PCR \\
\hline 140 & Japan & Asia & Male GU patients & 75 & 3 & 4 & Urethritis & 2000 & PCR \\
\hline 140 & Japan & Asia & Male NGU patients & 76 & 10 & 13.1 & Urethritis & 2000 & PCR \\
\hline 141 & Sweden & Europe & $\begin{array}{l}\text { Male STI clinic patients } \\
\text { (no urethritis) }\end{array}$ & 50 & 5 & 10 & Urethritis & 2000 & PCR \\
\hline 159 & China & Asia & Asympt controls & 238 & 5 & 2.1 & Urethritis & 2008 & PCR \\
\hline 160 & South Africa & South America & NGU patients & 96 & 16 & 16.7 & Urethritis & 2002 & PCR \\
\hline 161 & New Zealand & Australia & Asymptomatic & 199 & 4 & 2 & Urethritis & 2010 & PCR \\
\hline 162 & Italy & Europe & Asymptomatic & 23 & 1 & 4.3 & Urethritis & 1999 & PCR \\
\hline 163 & South Africa & Africa & Asymptomatic & 100 & 3 & 3 & Urethritis & 2004 & PCR \\
\hline 164 & South Africa & Africa & Urethritis patients & 665 & 115 & 17.3 & Urethritis & 2010 & TMA assay \\
\hline 165 & Russia & Asia & Asymptomatic & 30 & 3 & 10 & Urethritis & 2009 & PCR \\
\hline 122 & Sweden & Europe & Women at STI clinics & 283 & 18 & 6.3 & Urethritis, cervicitis & 2005 & PCR \\
\hline 20 & Tunisia & Africa & Infertile men & 120 & 6 & 5 & Infertility & 2011 & PCR \\
\hline
\end{tabular}

Abbreviations used: STI: sexually transmitted infection; NGU: nongonococcal urethritis; PCR: polymerase chain reaction; PID: pelvic inflammatory disease; PTL: preterm labor; LGTI: lower genital tract infection; BV: bacterial vaginosis. 
Table S3. Rates and clinical presentations of Mycoplasma hominis.

\begin{tabular}{|c|c|c|c|c|c|c|c|c|c|}
\hline $\begin{array}{c}\text { Study } \\
\text { number }\end{array}$ & Location & Continent & Population & $\begin{array}{l}\text { Total } \\
\text { tested }\end{array}$ & \#Positive & МН\% & Presentation & Year & $\begin{array}{l}\text { Diagnostic } \\
\text { method }\end{array}$ \\
\hline 2 & Japan & Asia & Male urethritis patients & 176 & 21 & 12 & Urethritis & 2011 & PCR \\
\hline 51 & Czech Republic & Europe & Male urethritis patients & 150 & 28 & 18.7 & Urethritis & 1992 & Culture \\
\hline 76 & USA (MT) & North America & Rural population & 2408 & 96 & 4 & Urethritis & 1987 & Culture \\
\hline 33 & Mexico & North America & $\begin{array}{l}\text { Primary care UTI } \\
\text { patients }\end{array}$ & 436 & 9 & 2 & UTI & 2002 & Culture \\
\hline 89 & Japan & Asia & $\begin{array}{l}\text { Pregnant women } \\
\text { w/preterm birth }\end{array}$ & 90 & 15 & 17 & Preterm labor & 1986 & Culture \\
\hline 169 & Sweden & Europe & $\begin{array}{l}\text { Pregnant women } \\
\text { w/preterm birth }\end{array}$ & 37 & 13 & 34.7 & Preterm labor & 2003 & Culture \\
\hline 7 & Russia & Europe & Prostate cancer patients & 125 & 26 & 20.5 & Prostate cancer & 2010 & PCR \\
\hline 7 & Russia & Europe & Prostate cancer patients & 118 & 36 & 30.5 & Prostate cancer & 2010 & Serology \\
\hline 167 & Russia & Asia & Prostate cancer patients & 247 & 65 & 26.2 & Prostate cancer & 2011 & PCR, serology \\
\hline 16 & Palestine & Middle East & Sterile pyuria patients & 200 & 2 & 1 & Pyuria & 2008 & PCR \\
\hline 64 & Croatia & Europe & $13-19$ years old & 126 & 18 & 14.3 & Relapsing cervicitis & 1989 & Culture \\
\hline 4 & Serbia & Europe & Heteros men & 299 & 24 & 8.02 & NGU & 2010 & $\begin{array}{l}\text { Mycoplasma } \\
\text { IST assay }\end{array}$ \\
\hline 32 & Israel & Middle East & Male STI clinic patients & 71 & 9 & 13.2 & NGU & 1996 & Culture \\
\hline 65 & Croatia & Europe & Urethritis patients & 184 & 26 & 14.13 & NGU & 1989 & Culture \\
\hline 71 & Greece & Europe & Urethritis female & 237 & 67 & 28.14 & NGU & 1988 & Culture \\
\hline 78 & Germany & Europe & Male urethritis patients & 169 & 8 & 4.7 & NGU & 1987 & Culture \\
\hline 120 & Brazil & South America & HIV neg men w/NGU & 110 & 1 & 0.9 & NGU & 2000 & $\begin{array}{l}\text { Culture- } \\
\text { PCR/RFLP }\end{array}$ \\
\hline 156 & USA & North America & NGU patients & 106 & 7 & 7 & NGU & 2001 & PCR \\
\hline 92 & Italy & Europe & Infertile men & 115 & 3 & 2.6 & Infertility & 1984 & Culture \\
\hline 28 & India (Bombay) & Asia & BV & 327 & 35 & 10.7 & BV & 1990 & Culture \\
\hline 143 & Ivory Coast & Africa & Pregnant women & 551 & 281 & 51 & BV & 2000 & Culture \\
\hline 148 & UK & Europe & Women with BV & 17 & 9 & 53 & BV & 2000 & Culture \\
\hline 90 & Denmark & Europe & $\begin{array}{c}\text { Female cervicitis; } \\
\text { partners of male NGU } \\
\text { patients }\end{array}$ & 85 & 31 & 36 & Cervicitis, urethritis & 1985 & Culture \\
\hline 147 & Brazil & South America & Women with UG signs & 77 & 4 & 5 & Cervicitis/salpingitis & 1987 & Culture \\
\hline 150 & Kenya & Africa & $\begin{array}{l}\text { Postpartum } \\
\text { endometritis }\end{array}$ & 35 & 19 & 53 & $\begin{array}{l}\text { Endometritis } \\
\text { (postpartum) }\end{array}$ & 1988 & Culture \\
\hline 95 & Germany & Europe & $\begin{array}{l}\text { Male gonococcal } \\
\text { urethritis patients }\end{array}$ & 143 & 19 & 13 & GC urethritis & 1983 & Culture \\
\hline 37 & Argentina & South America & Pregnant women w/BV & 198 & 28 & 14.1 & Genital discharge & 2001 & Culture \\
\hline 170 & $\begin{array}{c}\text { Kenya, } \\
\text { South Africa, } \\
\text { Swaziland }\end{array}$ & Africa & Men with UG lesions & 256 & 41 & 16 & Genital ulceration & 1983 & Culture \\
\hline $26^{*}$ & USA (Texas) & North America & Infertile men & 80 & 4 & 5 & Infertility & 1993 & Culture \\
\hline 30 & Turkey & Middle East & Infertile women & 50 & 4 & 8 & Infertility & 2002 & Culture \\
\hline 36 & Spain & Europe & Infertile people & 375 & 18 & 4.8 & Infertility & 2001 & Culture \\
\hline 43 & USA (Texas) & North America & Infertile women & 79 & 22 & 28 & Infertility & 1993 & Culture \\
\hline 145 & Russia & Asia & Infertile couples & 148 & 25 & 16.9 & Infertility & 2000 & PCR \\
\hline 13 & Tunisia & Africa & Infertile men & 116 & 12 & 10.3 & $\begin{array}{c}\text { Infertility, } \\
\text { lukocytospermia }\end{array}$ & 2008 & PCR \\
\hline 45 & Chile & South America & Infertile women & 47 & 10 & 21 & Infertility & 1993 & Culture \\
\hline 20 & Tunisia & Africa & Infertile men & 120 & 13 & 10.8 & LSC, ASM & 2007 & PCR \\
\hline 47 & China & Asia & VD patients & 239 & 10 & 4.18 & "VD" & 1990 & Serology \\
\hline
\end{tabular}

Abbreviations used: UG: urogenital; UTI: urinary tract infection; STI: sexually transmitted infection; NGU: nongonococcal urethritis; GU: gonococcal urethritis; PCR: polymerase chain reaction; PID: pelvic inflammatory disease; LSC: low sperm count; ASM: abnormal sperm morphology; LGTI: lower genital tract infection; BV: bacterial vaginosis; VD: venereal disease. 
Table S4. Rates and clinical presentations of Ureaplasma species.

\begin{tabular}{|c|c|c|c|c|c|c|c|c|c|}
\hline $\begin{array}{c}\text { Study } \\
\text { number }\end{array}$ & Location & Continent & Population & $\begin{array}{l}\text { Total } \\
\text { tested }\end{array}$ & \#Positive & Usp \% & Presentation & Year & $\begin{array}{c}\text { Diagnostic } \\
\text { method }\end{array}$ \\
\hline 96 & Canada (Toronto) & North America & Miscarriage & 71 & 60 & 84.5 & APO & 1983 & Serology \\
\hline 92 & Italy & Europe & Infertile men & 116 & 50 & 42.2 & $\begin{array}{l}\text { Bacteriospermia } \\
\text { infertility }\end{array}$ & 1984 & Culture \\
\hline 99 & Australia & Australia & $\begin{array}{l}\text { Pregnant women with } \\
\text { bacturia }\end{array}$ & 44 & 21 & 48 & Bacturia & 1981 & Culture \\
\hline 28 & India (Bombay) & Asia & BV & 325 & 151 & 46.5 & BV & 1990 & Culture \\
\hline 148 & UK & Europe & Women with BV & 17 & 11 & 65 & BV & 2000 & PCR \\
\hline 9 & Canada (Quebec) & North America & Pregnant women (CI) & 15 & 5 & 33 & Cervical insufficiency & 2008 & PCR \\
\hline 44 & Poland & Europe & $\begin{array}{l}\text { Cervical neoplasia } \\
\text { patients }\end{array}$ & 109 & 44 & 40.5 & $\begin{array}{l}\text { Cervical neoplasia } \\
\quad(\mathrm{HPV}+)\end{array}$ & 1993 & Culture \\
\hline 48 & Argentina & South America & Active women & 100 & 4 & 4 & Cervicitis & 1992 & Culture \\
\hline 147 & Brazil & South America & Women with UG signs & 51 & 30 & 58.5 & Cervicitis, salpingtitis & 1987 & Culture \\
\hline 67 & Mexico & North America & Non-pregnant women & 129 & 16 & 12.4 & Cervicovaginitis & 1989 & Culture \\
\hline 67 & Mexico & North America & Pregnant women & 105 & 21 & 20 & Cervicovaginitis & 1989 & Culture \\
\hline 68 & France & Europe & $\begin{array}{l}\text { Pregnant women- } \\
\text { chorioamnionitis }\end{array}$ & 160 & 69 & 43 & Chorioamnionitis & 1989 & Culture \\
\hline 22 & $\begin{array}{c}\text { USA } \\
\text { (New York) }\end{array}$ & North America & Preterm infants & 125 & 40 & 32 & CLD & 1999 & Culture \\
\hline 150 & Kenya & Africa & $\begin{array}{l}\text { Postpartum } \\
\text { endometritis }\end{array}$ & 30 & 23 & 77 & $\begin{array}{l}\text { Endometritis } \\
\text { (postpartum) }\end{array}$ & 1988 & Culture \\
\hline 10 & $\begin{array}{l}\text { USA } \\
\text { (13 sites) }\end{array}$ & North America & Women with PID & 50 & 16 & 32 & $\begin{array}{c}\text { Endometritis, PID, } \\
\text { BV }\end{array}$ & 2009 & PCR \\
\hline 37 & Argentina & South America & $\begin{array}{c}\text { Pregnant women } \\
\text { w/BV }\end{array}$ & 197 & 58 & 29.5 & Genital discharge & 2001 & Culture \\
\hline 44 & Poland & Europe & PID patients & 52 & 29 & 55.6 & GID & 1993 & Culture \\
\hline 95 & Germany & Europe & $\begin{array}{l}\text { Male gonococcal } \\
\text { urethritis patients }\end{array}$ & 144 & 49 & 34 & GU & 1983 & Culture \\
\hline 53 & Japan & Asia & GU patients & 146 & 46 & 31.5 & GU & 1988 & Culture \\
\hline 106 & USA (Seattle) & North America & $\begin{array}{l}\text { Urethral gonnorhea } \\
\text { patients }\end{array}$ & 122 & 45 & 37 & $\mathrm{Gu}$ & 1978 & Culture \\
\hline 100 & Scotland & Europe & $\begin{array}{l}\text { Male gonococcal } \\
\text { urethritis patients }\end{array}$ & 62 & 17 & 28 & GU & 1981 & Culture \\
\hline 26 & USA (Texas) & North America & Infertile & 79 & 22 & 28 & Infertility & 1993 & Culture \\
\hline 8 & Iran & Middle East & Infertile men & 100 & 12 & 12 & Infertility & 2007 & PCR \\
\hline 11 & Nigeria & Africa & Infertile women & 17 & 6 & 35.3 & Infertility & 2008 & PCR \\
\hline 14 & China (Nanjing) & Asia & Infertile men & 202 & 68 & 33.7 & Infertility & 2008 & Culture \\
\hline 29 & China (Hunan) & Asia & Infertile people & 768 & 281 & 36.59 & Infertility & 1998 & Culture \\
\hline 30 & Turkey & Middle East & Infertile women & 50 & 28 & 56 & Infertility & 2002 & Culture \\
\hline 36 & Spain & Europe & Infertile people & 374 & 88 & 23.5 & Infertility & 2001 & Culture \\
\hline 43 & USA (Texas) & North America & Infertile women & 80 & 4 & 5 & Infertility & 1993 & Culture \\
\hline 48 & Argentina & South America & Sterile/infertile women & 198 & 34 & 17.2 & Infertility & 1992 & Culture \\
\hline 56 & France & Europe & $\begin{array}{c}\text { Infe\#rtile } \\
\text { couples-males }\end{array}$ & 306 & 98 & 32 & Infertility & 1991 & Culture \\
\hline
\end{tabular}

Abbreviations used: UG: urogenital; UTI: urinary tract infection; STI: sexually transmitted infection; GID: genital inflammatory disease; NGU: nongonococcal urethritis; GU: gonococcal urethritis; PGU: postgonococcal urethritis; PCR: polymerase chain reaction; PID: pelvic inflammatory disease; LSC: low sperm count; BV: bacterial vaginosis; VD: venereal disease; PTL: preterm labor; PRM: premature rupture of membranes; LBW: low birth weight; CLD: chronic lung disease; APO: adverse pregnancy outcomes; MSM: men having sex with men; CI: cervical insufficiency; HPV: human papilloma virus. 
Table S5. Rates of all species in cases of urethritis.

\begin{tabular}{|c|c|c|c|c|c|c|c|c|c|}
\hline $\begin{array}{c}\text { Study } \\
\text { number }\end{array}$ & Location & Continent & Population & $\begin{array}{l}\text { Total } \\
\text { tested }\end{array}$ & $\begin{array}{c}\text { \#MG } \\
\text { positive }\end{array}$ & MG \% & Presentation & Year & $\begin{array}{c}\text { Diagnostic } \\
\text { method }\end{array}$ \\
\hline 131 & Norway & Europe & $\begin{array}{c}\text { Female STI clinic } \\
\text { patients }\end{array}$ & 7646 & 344 & $4.50 \%$ & LGTI, urethritis & 2009 & PCR \\
\hline 1 & USA (Seattle) & $\begin{array}{l}\text { North } \\
\text { America }\end{array}$ & Men STI clinic & 370 & 46 & $12.50 \%$ & NGU & 2011 & PCR \\
\hline 17 & $\begin{array}{l}\text { China (Hong } \\
\text { Kong) }\end{array}$ & Asia & $\begin{array}{l}\text { Male STI clinic } \\
\text { patients }\end{array}$ & 36 & 5 & $13.90 \%$ & NGU & 2007 & PCR \\
\hline 120 & Brazil & $\begin{array}{c}\text { South } \\
\text { America }\end{array}$ & $\begin{array}{l}\text { HIV-men with } \\
\text { NGU }\end{array}$ & 110 & 10 & $9.10 \%$ & NGU & 2000 & $\begin{array}{l}\text { Culture- } \\
>\text { PCR/RFLP }\end{array}$ \\
\hline 149 & $\begin{array}{l}\text { Central African } \\
\text { Republic }\end{array}$ & Africa & Asymptomatic men & 100 & 15 & $15 \%$ & NGU & 2001 & PCR \\
\hline 156 & USA & $\begin{array}{l}\text { North } \\
\text { America }\end{array}$ & $\begin{array}{l}\text { Asymptomatic } \\
\text { controls }\end{array}$ & 125 & 5 & $4 \%$ & NGU & 2001 & PCR \\
\hline 157 & $\begin{array}{l}\text { USA (New } \\
\text { Orleans) }\end{array}$ & $\begin{array}{l}\text { North } \\
\text { America }\end{array}$ & $\begin{array}{l}\text { Asymptomatic } \\
\text { controls }\end{array}$ & 184 & 13 & $7 \%$ & NGU & 2002 & PCR \\
\hline 158 & Venezuela & $\begin{array}{c}\text { South } \\
\text { America }\end{array}$ & $\begin{array}{l}\text { Asymptomatic } \\
\text { controls }\end{array}$ & 172 & 7 & $4.10 \%$ & NGU & 2008 & PCR \\
\hline 117 & Japan & Asia & Men with GU & 45 & 2 & $4.40 \%$ & $\begin{array}{l}\text { Postgonococcal } \\
\text { urethritis }\end{array}$ & 1996 & PCR \\
\hline 16 & Palestine & Middle East & $\begin{array}{l}\text { Sterile pyuria } \\
\text { patients }\end{array}$ & 200 & 6 & $3 \%$ & Pyuria & 2008 & PCR \\
\hline 136 & $\begin{array}{l}\text { West Africa ( } 7 \\
\text { Countries) }\end{array}$ & Africa & $\begin{array}{l}\text { Male urethritis } \\
\text { Patients }\end{array}$ & 659 & 66 & $10 \%$ & Urethral discharge & 2001 & PCR \\
\hline 2 & Japan & Asia & $\begin{array}{l}\text { Male urethritis } \\
\text { patients }\end{array}$ & 178 & 32 & $18 \%$ & Urethritis & 2011 & PCR \\
\hline 116 & $\begin{array}{l}\text { USA (Balti- } \\
\text { more) }\end{array}$ & $\begin{array}{l}\text { North } \\
\text { America }\end{array}$ & Men at STI clinics & 153 & 34 & $22.20 \%$ & Urethritis & 2009 & PCR \\
\hline 122 & Sweden & Europe & Men at STI clinics & 451 & 27 & $6 \%$ & Urethritis & 2005 & PCR \\
\hline 140 & Japan & Asia & Male GU patients & 75 & 3 & $4 \%$ & Urethritis & 2000 & PCR \\
\hline 140 & Japan & Asia & $\begin{array}{l}\text { Male NGU } \\
\text { patients }\end{array}$ & 76 & 10 & $13.10 \%$ & Urethritis & 2000 & PCR \\
\hline 141 & Sweden & Europe & $\begin{array}{l}\text { Male STI Clinic } \\
\text { patients }\end{array}$ & 50 & 5 & $10.00 \%$ & Urethritis & 2000 & PCR \\
\hline 159 & China & Asia & $\begin{array}{l}\text { Asymptomatic } \\
\text { controls }\end{array}$ & 238 & 5 & $2.10 \%$ & Urethritis & 2008 & PCR \\
\hline 160 & South Africa & Africa & NGU patients & 96 & 16 & $16.70 \%$ & Urethritis & 2002 & PCR \\
\hline 161 & New Zealand & Australia & Asymptomatic & 199 & 4 & $2 \%$ & Urethritis & 2010 & PCR \\
\hline 162 & Italy & Europe & Asymptomatic & 23 & 1 & $4.30 \%$ & Urethritis & 1999 & PCR \\
\hline 163 & South Africa & Africa & Asymptomatic & 100 & 3 & $3 \%$ & Urethritis & 2004 & PCR \\
\hline 164 & South Africa & Africa & Urethritis patients & 665 & 115 & $17.30 \%$ & Urethritis & 2010 & TMA assay \\
\hline 165 & Russia & Asia & Asymptomatic & 30 & 3 & $10 \%$ & Urethritis & 2009 & PCR \\
\hline 122 & Sweden & Europe & $\begin{array}{l}\text { Women at STI } \\
\text { clinics }\end{array}$ & 283 & 18 & $6.30 \%$ & Urethritis, cervicitis & 2005 & PCR \\
\hline $\begin{array}{l}\text { Study } \\
\text { number }\end{array}$ & Location & Continent & Population & $\begin{array}{l}\text { Total } \\
\text { tested }\end{array}$ & $\begin{array}{c}\text { \#MH } \\
\text { positive }\end{array}$ & МH \% & Presentation & Year & $\begin{array}{l}\text { Diagnostic } \\
\text { method }\end{array}$ \\
\hline 2 & Japan & Asia & $\begin{array}{l}\text { Male urethritis } \\
\text { patients }\end{array}$ & 176 & 21 & $12 \%$ & Urethritis & 2011 & PCR \\
\hline 51 & Czech Republic & Europe & $\begin{array}{l}\text { Male urethritis } \\
\text { patients }\end{array}$ & 150 & 28 & $18.70 \%$ & Urethritis & 1992 & Culture \\
\hline 76 & USA (MT) & $\begin{array}{l}\text { North } \\
\text { America }\end{array}$ & Rural population & 2408 & 96 & $4 \%$ & Urethritis & 1987 & Culture \\
\hline 33 & Mexico & $\begin{array}{c}\text { North } \\
\text { America }\end{array}$ & $\begin{array}{c}\text { Primary care UTI } \\
\text { patients }\end{array}$ & 436 & 9 & $2 \%$ & UTI & 2002 & Culture \\
\hline
\end{tabular}


Continued

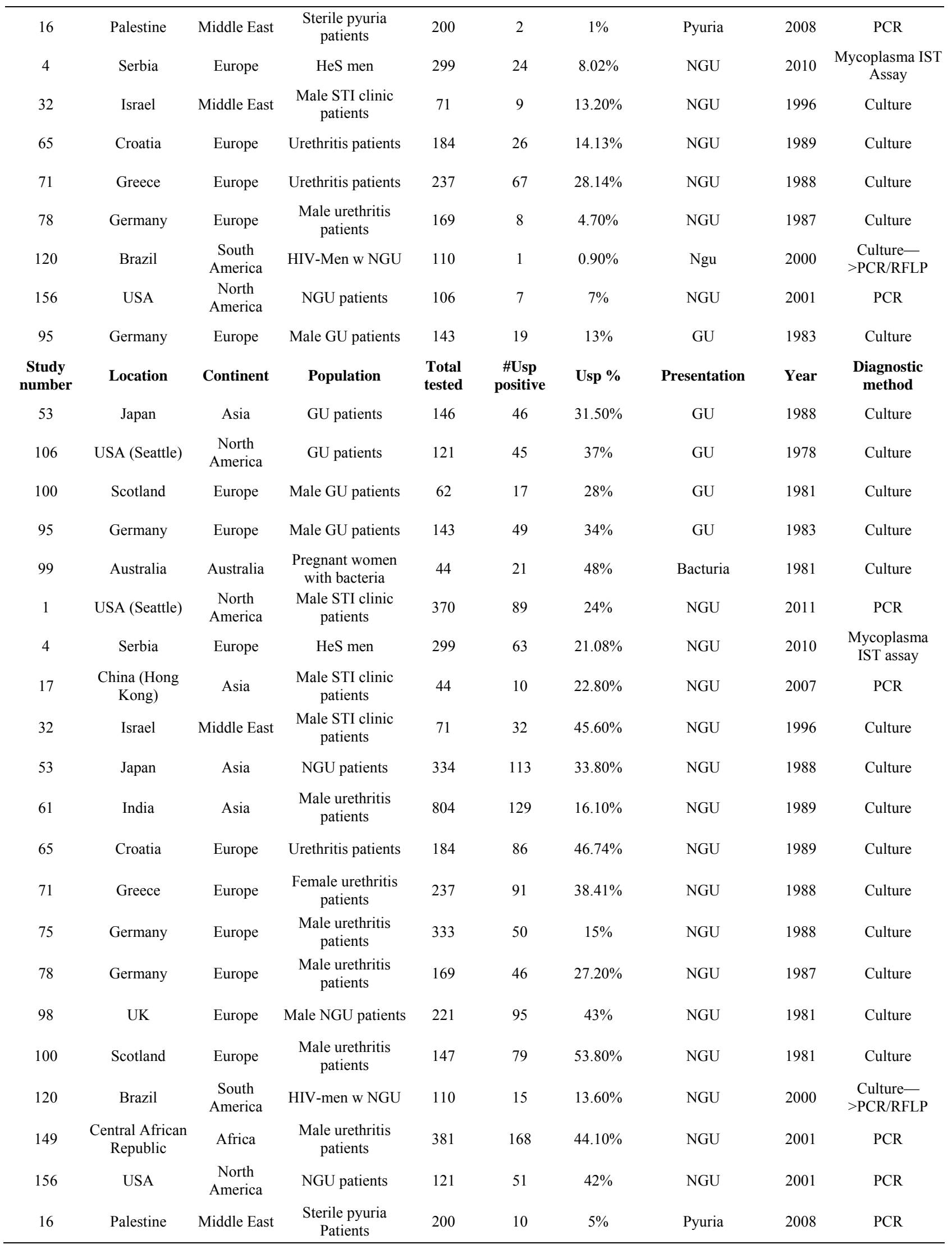




\section{Continued}

\begin{tabular}{|c|c|c|c|c|c|c|c|c|c|}
\hline 144 & Malaysia & Asia & Male STI clinic & 100 & 34 & $34 \%$ & PGU, NGU & 2003 & Culture \\
\hline 2 & Japan & Asia & $\begin{array}{l}\text { Male urethritis } \\
\text { patients }\end{array}$ & 176 & 21 & $12 \%$ & Urethritis & 2011 & PCR \\
\hline 51 & Czech Republic & Europe & $\begin{array}{l}\text { Male urethritis } \\
\text { patients }\end{array}$ & 150 & 73 & $48.70 \%$ & Urethritis & 1992 & Culture \\
\hline 55 & Spain (Seville) & Europe & MSM & 40 & 5 & $12.50 \%$ & Urethritis & 1991 & Culture \\
\hline 58 & $\begin{array}{c}\text { France } \\
\text { (Toulouse) }\end{array}$ & Europe & $\begin{array}{l}\text { Male urethritis } \\
\text { patients }\end{array}$ & 225 & 46 & $20.40 \%$ & Urethritis & 1991 & Culture \\
\hline 76 & USA (MT) & $\begin{array}{l}\text { North } \\
\text { America }\end{array}$ & Rural population & 2408 & 650 & $27 \%$ & Urethritis & 1987 & Culture \\
\hline 107 & Germany & Europe & Male NGU patients & 99 & 42 & $42 \%$ & Urethritis & 1997 & Culture \\
\hline 107 & Germany & Europe & Male NGU patients & 67 & 36 & $53 \%$ & Urethritis & 1977 & Culture \\
\hline 146 & Thailand & Asia & $\begin{array}{l}\text { Male urethritis } \\
\text { patients }\end{array}$ & 303 & 136 & $45 \%$ & Urethritis & 1989 & Culture \\
\hline 153 & India & Asia & GTI-urethritis & 356 & 171 & $48 \%$ & Urethritis & 2008 & PCR \\
\hline 155 & USA & $\begin{array}{l}\text { North } \\
\text { America }\end{array}$ & Urethritis patients & 119 & 31 & $26 \%$ & Urethritis & 2010 & PCR \\
\hline 159 & China & Asia & Urethritis patients & 100 & 22 & $22.10 \%$ & Urethritis & 2008 & PCR \\
\hline 163 & South Africa & Africa & NGU patients & 336 & 121 & $36 \%$ & Urethritis & 2004 & PCR \\
\hline 152 & Nigeria & Africa & $\begin{array}{l}\text { Vaginal discharge/ } \\
\text { inflammation }\end{array}$ & 17 & 10 & $59 \%$ & Urethritis/BV & 2008 & PCR \\
\hline 12 & UK & Europe & Women w/UTI & 288 & 75 & $26 \%$ & UTI & 2008 & Culture \\
\hline 33 & Mexico & $\begin{array}{l}\text { North } \\
\text { America }\end{array}$ & UTI patients & 436 & 26 & $5.90 \%$ & UTI & 2002 & Culture \\
\hline 151 & Egypt & Africa & $\begin{array}{l}\text { Men with struvite } \\
\text { stones }\end{array}$ & 30 & 8 & $26.70 \%$ & Struvite formation & 1996 & Culture \\
\hline
\end{tabular}

Abbreviations: UG: urogenital; GTI: genital tract infection; UTI: urinary tract infections; STI: sexually transmitted infection; NGU: nongonococcal urethritis; GU: gonococcal urethritis; PGU: postgonococcal urethritis; PCR: polymerase chain reaction; PID: pelvic inflammatory disease; LSC: low sperm count; ASM: abnormal sperm morphology; LGTI: lower gential tract; BV: bacterial vaginosis; VD: venereal disease; PTL: preterm labor; INF: infertility; INFL: inflammatory conditions (i.e., bacterial vaginosis, cervicitis, pelvic inflammatory disease); PC: prostate cancer; LBW/CLD: low birth weight and/or chronic lung disease of infants; ND: no description of specific clinical signs while being distinguished from asymptomatic patients; Hes: Heterosexual; RFLP: restriction fragment length polymorphism.

Table S6. Rates of all species in cases of preterm labor and adverse pregnancy outcomes.

\begin{tabular}{|c|c|c|c|c|c|c|c|c|c|}
\hline $\begin{array}{c}\text { Study } \\
\text { number }\end{array}$ & Location & Continent & Population & $\begin{array}{l}\text { Total } \\
\text { tested }\end{array}$ & \#Positive & MG \% & Presentation & Year & $\begin{array}{c}\begin{array}{c}\text { Diagnostic } \\
\text { method }\end{array} \\
\end{array}$ \\
\hline 112 & Peru & $\begin{array}{c}\text { South } \\
\text { America }\end{array}$ & Pregnant women & 650 & 13 & $2 \%$ & Preterm labor & 2010 & PCR \\
\hline $\begin{array}{c}\text { Study } \\
\text { number }\end{array}$ & Location & Continent & Population & $\begin{array}{l}\text { Total } \\
\text { tested }\end{array}$ & \#Positive & МH\% & Presentation & Year & $\begin{array}{c}\text { Diagnostic } \\
\text { method }\end{array}$ \\
\hline 89 & Japan & Asia & Pregnant women & 88.23529 & 15 & $17 \%$ & Preterm labor & 1986 & Culture \\
\hline 169 & Sweden & Europe & Pregnant women & 37.46398 & 13 & $34.70 \%$ & Preterm labor & 2003 & Culture \\
\hline $\begin{array}{c}\text { Study } \\
\text { number }\end{array}$ & Location & Continent & Population & $\begin{array}{l}\text { Total } \\
\text { tested }\end{array}$ & \#Positive & Usp\% & Presentation & Year & $\begin{array}{c}\text { Diagnostic } \\
\text { method }\end{array}$ \\
\hline 50 & France & Europe & Pregnant women & 191 & 103.14 & $54 \%$ & Preterm labor & 1992 & Culture \\
\hline 89 & Japan & Asia & Pregnant women & 90 & 72 & $80 \%$ & Preterm labor & 1986 & Culture \\
\hline 15 & Czech Republic & Europe & Pregnant women & 75 & 72 & $96 \%$ & PTL/PRM & 2008 & Culture \\
\hline 81 & Belgium & Europe & $\begin{array}{l}\text { Recurrent } \\
\text { miscarriage }\end{array}$ & 76 & 49.02 & $64.50 \%$ & $\begin{array}{l}\text { Recurrent } \\
\text { miscarriage }\end{array}$ & 1987 & Culture \\
\hline 81 & Belgium & Europe & Miscarriage & 122.0075 & 65.03 & $53.30 \%$ & Miscarriage & 1987 & Culture \\
\hline 82 & Canada & $\begin{array}{l}\text { North } \\
\text { America }\end{array}$ & $\begin{array}{l}\text { Spontaneous } \\
\text { abortion }\end{array}$ & 264 & 63.36 & $24 \%$ & Miscarriage & 1986 & Culture \\
\hline 9 & Canada (Quebec) & $\begin{array}{l}\text { North } \\
\text { America }\end{array}$ & $\begin{array}{l}\text { Pregnant women } \\
\text { (Cl) }\end{array}$ & 15.15152 & 5 & $33 \%$ & $\begin{array}{c}\text { Cervical } \\
\text { insufficiency }\end{array}$ & 2008 & PCR \\
\hline 68 & France & Europe & $\begin{array}{l}\text { Pregnant women } \\
\text { chorioamnionitis }\end{array}$ & 160 & 68.8 & $43 \%$ & Chorioamnionitis & 1989 & Cutlure \\
\hline 96 & Canada (Toronto) & $\begin{array}{l}\text { North } \\
\text { America }\end{array}$ & Miscarriage & 71 & 59.995 & $84.50 \%$ & APO & 1983 & Serology \\
\hline
\end{tabular}

Abbreviations used: PTL: preterm labor; PRM: premature rupture of membranes; APO: adverse pregnancy outcomes. 
Table S7. Rates of all species in cases of infertility.

\begin{tabular}{|c|c|c|c|c|c|c|c|c|c|}
\hline $\begin{array}{c}\text { Study } \\
\text { number }\end{array}$ & Location & Continent & Population & $\begin{array}{c}\text { Total } \\
\text { tested }\end{array}$ & \#Positive & MG\% & Presentation & Year & $\begin{array}{c}\text { Diagnostic } \\
\text { method }\end{array}$ \\
\hline 20 & Tunisia & Africa & Infertile men & 120 & 6 & $5 \%$ & Infertility & 2009 & PCR \\
\hline 135 & Denmark & Europe & Infertile women & 132 & 29 & $22 \%$ & Infertility & 2000 & Serology \\
\hline $\begin{array}{l}\text { Study } \\
\text { number }\end{array}$ & Location & Continent & Population & $\begin{array}{l}\text { Total } \\
\text { tested }\end{array}$ & \#Positive & МН\% & Presentation & Year & $\begin{array}{c}\text { Diagnostic } \\
\text { method }\end{array}$ \\
\hline $26^{*}$ & USA (Texas) & North America & Infertile & 80 & 4 & $5 \%$ & Infertility & 1993 & Culture \\
\hline 30 & Turkey & Middle East & Infertile women & 50 & 4 & $8 \%$ & Infertility & 2002 & Culture \\
\hline 36 & Spain & Europe & Infertile people & 375 & 18 & $4.80 \%$ & Infertility & 2001 & Culture \\
\hline 43 & USA (Texas) & North America & Infertile women & 79 & 22 & $28 \%$ & Infertility & 1993 & Culture \\
\hline 13 & Tunisia & Africa & Infertile men & 116 & 12 & $10.30 \%$ & $\begin{array}{c}\text { Infertility, } \\
\text { lukocytospermia }\end{array}$ & 2008 & PCR \\
\hline 45 & Chile & South America & Infertile women & 47 & 10 & $21 \%$ & Infertility & 1993 & Culture \\
\hline 20 & Tunisia & Africa & Infertile men & 120 & 13 & $10.80 \%$ & LSC, ASM & 2007 & PCR \\
\hline 92 & Italy & Europe & Infertile men & 115 & 3 & $2.60 \%$ & Infertility & 1984 & Culture \\
\hline $\begin{array}{l}\text { Study } \\
\text { number }\end{array}$ & Location & Continent & Population & $\begin{array}{c}\text { Total } \\
\text { tested }\end{array}$ & \#Positive & Usp \% & Presentation & Year & $\begin{array}{c}\text { Diagnostic } \\
\text { method }\end{array}$ \\
\hline 92 & Italy & Europe & Infertile men & 116 & 49 & $42.20 \%$ & $\begin{array}{c}\text { Bacteriospermia, } \\
\text { infertility }\end{array}$ & 1984 & Culture \\
\hline 20 & Tunisia & Africa & Infertile men & 120 & 18 & $15 \%$ & LSC, ASM & 2007 & PCR \\
\hline 88 & Netherlands & Europe & Infertile Men & 121 & 40 & $33 \%$ & LSC, ASM & 1986 & Culture \\
\hline 8 & Iran & Middle East & Infertile men & 100 & 12 & $12 \%$ & Infertility & 2007 & PCR \\
\hline 11 & Nigeria & Africa & Infertile women & 17 & 6 & $35.30 \%$ & Infertility & 2008 & PCR \\
\hline 14 & China (Nanjing) & Asia & Infertile men & 202 & 68 & $33.70 \%$ & Infertility & 2008 & Culture \\
\hline 29 & China (Hunan) & Asia & Infertile people & 768 & 281 & $36.59 \%$ & Infertility & 1998 & Culture \\
\hline 30 & Turkey & Middle East & Infertile women & 50 & 28 & $56 \%$ & Infertility & 2002 & Culture \\
\hline 36 & Spain & Europe & Infertile people & 374 & 88 & $23.50 \%$ & Infertility & 2001 & Culture \\
\hline 43 & USA (Texas) & North America & Infertile women & 79 & 4 & $5 \%$ & Infertility & 1993 & Culture \\
\hline 48 & Argentina & South America & Infertile women & 198 & 34 & $17.20 \%$ & Infertility & 1992 & Culture \\
\hline 56 & France & Europe & $\begin{array}{c}\text { Infertile } \\
\text { couples-males }\end{array}$ & 306 & 98 & $32.00 \%$ & Infertility & 1991 & Culture \\
\hline 56 & France & Europe & $\begin{array}{l}\text { Infertile couples } \\
\text { (at least one } \\
\text { partner) }\end{array}$ & 306 & 129 & $42.00 \%$ & Infertility & 1991 & Culture \\
\hline 145 & Russia & Asia & $\begin{array}{l}\text { Infertile } \\
\text { couples }\end{array}$ & 246 & 96 & $39 \%$ & Infertility & 2000 & PCR \\
\hline 152 & Nigeria & Africa & Infertile women & 17 & 6 & $35 \%$ & Infertility & 2008 & PCR \\
\hline 13 & Tunisia & Africa & Infertile men & 116 & 18 & $15.50 \%$ & $\begin{array}{c}\text { Infertility, } \\
\text { Lukocytospermia }\end{array}$ & 2008 & PCR \\
\hline 45 & Chile & South America & Infertile women & 47 & 22 & $47 \%$ & Infertility & 1993 & Culture \\
\hline 24 & China (Hunan) & Asia & Infertile men & 789 & 281 & $35.60 \%$ & Infertility & 1998 & Culture \\
\hline
\end{tabular}

Abbreviations used: LSC: low sperm count; ASM: Abnormal sperm morphology. 
Table S8. Rates of all species in cases of genital inflammation including bacterial vaginosis, cervicitis, pelvic inflammatory disease, and nonspecific inflammatory conditions.

\begin{tabular}{|c|c|c|c|c|c|c|c|c|c|}
\hline $\begin{array}{c}\text { Study } \\
\text { number }\end{array}$ & Location & Continent & Population & $\begin{array}{l}\text { Total } \\
\text { tested }\end{array}$ & \#Positive & MG\% & Presentation & Year & $\begin{array}{c}\text { Diagnostic } \\
\text { method }\end{array}$ \\
\hline 115 & $\begin{array}{c}\text { USA } \\
\text { (Baltimore) }\end{array}$ & North America & $\begin{array}{l}\text { Women at STI } \\
\text { clinics }\end{array}$ & 324 & 93 & $28.60 \%$ & Cervicitis & 2009 & PCR \\
\hline 139 & Japan & Asia & $\begin{array}{l}\text { Women with } \\
\text { cervicitis/ } \\
\text { adnexitis }\end{array}$ & 103 & 7 & $6.80 \%$ & cervicitis/ adnexitis & 1997 & PCR \\
\hline 133 & UK & Europe & PID Patients & 46 & 6 & $13 \%$ & PID & 2003 & PCR \\
\hline 114 & Sweden & Europe & $\begin{array}{c}\text { Pregnant } \\
\text { women-induced } \\
\text { abortion }\end{array}$ & 1960 & 49 & $2.50 \%$ & Post-term PID & 2007 & PCR \\
\hline $\begin{array}{l}\text { Study } \\
\text { number }\end{array}$ & Location & Continent & Population & $\begin{array}{l}\text { Total } \\
\text { tested }\end{array}$ & \#Positive & МH\% & Presentation & Year & $\begin{array}{c}\text { Diagnostic } \\
\text { method }\end{array}$ \\
\hline 64 & Coatia & Europe & 13-19 year olds & 126 & 18 & $14.30 \%$ & Relapsing Cervicitis & 1989 & Culture \\
\hline 28 & India (Bombay) & Asia & BV patients & 327 & 35 & $10.70 \%$ & BV & 1990 & Culture \\
\hline 143 & Ivory Coast & Africa & Pregnant women & 551 & 281 & $51 \%$ & BV & 2000 & Culture \\
\hline 148 & UK & Europe & Women with BV & 17 & 9 & $53 \%$ & BV & 2000 & PCR \\
\hline 90 & Denmark & Europe & $\begin{array}{l}\text { Female partners } \\
\text { of male NGU } \\
\text { Patients }\end{array}$ & 85 & 31 & $36 \%$ & Cervicitis, urethritis & 1985 & Culture \\
\hline 147 & Brazil & South America & $\begin{array}{l}\text { Women with UG } \\
\text { signs }\end{array}$ & 77 & 4 & $5 \%$ & Cervicitis/salpingitis & 1987 & Culture \\
\hline 150 & Kenya & Africa & $\begin{array}{l}\text { Postpartum } \\
\text { edomertritis }\end{array}$ & 35 & 19 & $53 \%$ & $\begin{array}{l}\text { Endometritis } \\
\text { (postpartum) }\end{array}$ & 1988 & Culture \\
\hline 37 & Argentina & South America & $\begin{array}{l}\text { Pregnant women } \\
\text { with BV }\end{array}$ & 198 & 28 & $14.10 \%$ & Genital Discharge & 2001 & Culture \\
\hline 170 & $\begin{array}{l}\text { Kenya/ South } \\
\text { Africa/ } \\
\text { Swaziland }\end{array}$ & Africa & $\begin{array}{l}\text { Men with UG } \\
\text { lesions }\end{array}$ & 256 & 41 & $16 \%$ & Genital Ulceration & 1983 & Culture \\
\hline 170 & South Africa & Africa & $\begin{array}{l}\text { Men with UG } \\
\text { lesions }\end{array}$ & 0 & 0 & $16 \%$ & Genital Ulceration & 1983 & Culture \\
\hline 170 & Swaziland & Africa & $\begin{array}{l}\text { Men with UG } \\
\text { lesions }\end{array}$ & 0 & 0 & $16 \%$ & Genital Ulceration & 1983 & Culture \\
\hline 47 & China & Asia & "VD" Patients & 239 & 10 & $4.18 \%$ & "VD" & 1990 & Serology \\
\hline $\begin{array}{l}\text { Study } \\
\text { number }\end{array}$ & Location & Continent & Population & $\begin{array}{l}\text { Total } \\
\text { tested }\end{array}$ & \#Positive & Usp\% & Presentation & Year & $\begin{array}{c}\text { Diagnostic } \\
\text { method }\end{array}$ \\
\hline 3 & Turkey & Middle East & Pregnant women & 96 & 25 & $26 \%$ & $\begin{array}{l}\text { Subclinical cervical } \\
\text { infection }\end{array}$ & 2010 & PCR \\
\hline 64 & Croatia & Europe & $13-19$ years old & 126 & 38 & $30.20 \%$ & Relapsing cervicitis & 1989 & Culture \\
\hline 28 & India (Bombay) & Asia & BV patients & 325 & 151 & $46.50 \%$ & BV & 1990 & Culture \\
\hline 148 & UK & Europe & Women with BV & 17 & 11 & $65 \%$ & BV & 2000 & PCR \\
\hline 44 & Poland & Europe & $\begin{array}{c}\text { Cervical } \\
\text { neoplasia } \\
\text { patients }\end{array}$ & 109 & 44 & $40.50 \%$ & $\begin{array}{l}\text { Cervical Neoplasia } \\
(\mathrm{HPV}+)\end{array}$ & 1993 & Culture \\
\hline 48 & Argentina & South America & Active women & 100 & 4 & $4.00 \%$ & Cervicitis & 1992 & Culture \\
\hline 147 & Brazil & South America & $\begin{array}{l}\text { Women with UG } \\
\text { signs }\end{array}$ & 51 & 30 & $58.50 \%$ & $\begin{array}{l}\text { Cervicitis/ } \\
\text { salpingitis }\end{array}$ & 1987 & Culture \\
\hline 67 & Mexico & North America & $\begin{array}{l}\text { Non-pregnant } \\
\text { women }\end{array}$ & 129 & 16 & $12.40 \%$ & Cervicovaginitis & 1989 & Culture \\
\hline 67 & Mexico & North America & Pregnant women & 105 & 21 & $20.00 \%$ & Cervicovaginitis & 1989 & Culture \\
\hline 150 & Kenya & Africa & $\begin{array}{l}\text { Postpartum } \\
\text { endometritis }\end{array}$ & 30 & 23 & $77 \%$ & Endometritus & 1988 & Culture \\
\hline 10 & USA (13 sites) & North America & Women with PID & 50 & 16 & $32 \%$ & $\begin{array}{c}\text { Endometritis, PID, } \\
\text { BV }\end{array}$ & 2009 & PCR \\
\hline 37 & Argentina & South America & $\begin{array}{l}\text { Pregnant women } \\
\text { with BV }\end{array}$ & 198 & 58 & $29.50 \%$ & Genital Discharge & 2001 & Culture \\
\hline 44 & Poland & Europe & PID patients & 52 & 29 & $55.60 \%$ & $\begin{array}{c}\text { Genital } \\
\text { Inflammatory } \\
\text { Disease }\end{array}$ & 1993 & Culture \\
\hline 47 & China & Asia & "VD" patients & 239 & 42 & $17.57 \%$ & "VD" & 1990 & Serology \\
\hline
\end{tabular}

Abbreviations: UG: urogenital; STI: sexually transmitted infection; PCR: polymerase chain reaction; PID: pelvic inflammatory disease; BV: bacterial vaginosis; VD: venereal disease. 